WORKING PAPER: 8-26-09

\title{
CREATIVE DESTRUCTION, ECONOMIC INSECURITY, STRESS AND EPIDEMIC OBESITY
}

\begin{abstract}
Jon D. Wisman and Kevin Capehart ${ }^{1}$
"I confess I am not charmed with the ideal of life held out by those who think that the normal state of human beings is that of struggling to get on; that the trampling, crushing, elbowing, and treading on each other's heels, which form the existing type of social life, are the most desirable lot of humankind, or anything but the disagreeable by symptoms of one of the phases of industrial progress" (Mill 1848: 748).

"Thus we have been expressly evolved by nature—with all our impulses and deepest instincts - for the purpose of solving the economic problem ['the struggle for subsistence']. If the economic problem is solved, mankind will be deprived of its traditional purpose...W Will this be a benefit? If one believes at all in the real values of life, the prospect at least opens up the possibility of benefit. Yet I think with dread of the readjustment of the habits and instincts of the ordinary man, bred into him for countless generations, which he may be asked to discard within a few decades" (Keynes 1932: 366).
\end{abstract}

"Under the Darwinian norm it must be held that men's reasoning is largely controlled by other than logical, intellectual forces" (Veblen 1919: 441).

\begin{abstract}
The percentage of Americans who are obese has doubled since 1980. Most attempts to explain this "obesity epidemic" have been found inadequate, including the "Big Two" (the increased availability of inexpensive food and the decline of physical exertion). This article explores the possibility that the obesity epidemic is substantially due to growing insecurity, stress, and a sense of powerlessness in modern society where high-sugar and high-fat foods are increasingly omnipresent. Those suffering these conditions may suffer less control over other domains of their lives. Insecurity and stress have been found to increase the desire for high-fat and high sugar foods. After exploring the evidence of a link between stress and obesity, the increasing pace of capitalism's creative destruction and its generation of greater insecurity and stress are addressed. The article ends with reflections on how epidemic obesity is symptomatic of a social mistake - the seeking of maximum efficiency and economic growth even in societies where the fundamental problem of material security has been solved.
\end{abstract}

Keywords: Social gradient obesity; endogenous preferences, cortisol, inequality, thrifty genes, rational choice model.

The prevalence of obesity among American adults has been increasing for at least 100 years (Helmchen and Henderson 2004) and in recent decades at an increasing rate. Relatively stable from 1960 - when nationally representative data were first collected - until 1980, the prevalence of obesity has since doubled. Extreme obesity has tripled to about five percent of all adults. ${ }^{1}$ Obesity increased dramatically for adults of each gender and every age, race, ethnicity, and socioeconomic status (SES) group studied. Nearly one-third (32.2 percent) of the adult population is now considered obese, and nearly two-thirds (66.3 percent) of the adult population is considered overweight. $^{2}$ The related health risks, including Type II diabetes, heart disease, hypertension, stroke, certain

\footnotetext{
${ }^{1}$ The authors are Professor of Economics and Ph.D. Candidate in Economics, respectively, at American University, Washington, D.C. Helpful comments from Mary E. Hansen and Martha Starr are gratefully acknowledged.
} 
cancers, and possibly dementia (Whitmer, et. al. 2008), are making obesity a leading cause of preventable disease and death. By some estimates, only tobacco use causes more preventable deaths. This increasing obesity problem has been likened to an epidemic (Flegal 2006; Wang and Beydoun 2007).

In addition to the U.S., other developed countries have also experienced dramatic increases in obesity since 1980 (WHO 2000). In the United Kingdom, for example, the prevalence of obesity among adults has almost tripled since 1980 (Rennie and Jebb 2005). In a number of former Warsaw Pact countries, obesity levels are almost as high as in the U.S. (Cutler, Glaeser, and Shapiro 2003: 98). More recently, obesity has even been recognized as a public health concern in developing countries. ${ }^{3}$ Today, for the first time in human history, there are more overweight than underweight adults in the world. ${ }^{4}$ There are approximately 1.3 billion overweight adults and 800 million underweight adults. Of the former, over 300 million are considered obese, the majority residing in developed countries.

No one seriously contends that genetic changes over the past three decades can account for this epidemic. Therefore, it must be a natural, albeit undesired, response to changes in the environment. These changes have increased forms of behavior that increase the likelihood of positive energy balance -- where calorie intake exceeds expenditure (Hill and Peters 1998: 1371).

The two principle environmental reasons given for the American obesity epidemic (the "Big Two") are decreasing cost and increasing availability of food, especially in the form of fast or junk food high in fat and sugar, and the decline of physical exertion, most notably at work (Keith et. al. 2006). Although there is surely some truth to these claims, they do not seem capable of explaining the full extent and timing of the explosion in obesity. Throughout much of history, the very wealthy have had food - even fat-rich and high-sugar foods - readily available. Further, they had servants and thus labored little. Although sometimes plump - a mark of high status they were not typically obese. Surveying the evidence, Keith et. al. (2006) conclude that undue attention has been given to the Big Two, resulting in neglect of ten other equally plausible mechanisms.

This article explores a potential socially-generated cause of obesity not included in the list provided by Keith et. al. -- the possibility that the obesity epidemic is substantially due to increased insecurity and stress in an environment in which there is ready availability of high-fat and high-sugar foods ${ }^{5}$ As will be seen below, an emerging body of research establishes a highly probable association of insecurity, stress, and weight gain. 
Physiologically, stress leads individuals to prefer fatty and sweet foods, and frequently to consume more calories, exacerbating weight gain, especially in the highly dangerous form of abdominal fat. ${ }^{6}$

The past three decades have witnessed a substantial increase in insecurity and stress as capitalism's creative destruction has become ever-more robust. Jobs and incomes have become less secure. Social status is increasingly threatened by rising inequality. Soaring health care costs have made adequate health care less available. Whether income will be sufficient during retirement is increasingly in question. Social capital and neighborhood cohesion have weakened. Peoples worldwide appear ever-more time-stressed and concerned about their futures.

The claim of a link between insecurity, stress, and obesity is strongly suggested by the fact that the incidence of obesity is greater among the least privileged in society, the most economically insecure (i.e., social gradient obesity); ${ }^{7}$ those with the least control over their lives and critical sources of self-worth; e.g., African American and Mexican American women (Hedley, et. al. 2004; Flegal, et. al. 2002).

This article begins with a survey of the dominant explanations of the obesity epidemic and their limitations. The second section surveys research that is supportive of a relationship between insecurity, stress and obesity. The third section provides evidence of the rise of insecurity and stress as creative destruction has gathered momentum over the past three decades. The fourth section examines the oddity of a stable obesity rate between 1960 and 1980 . The fifth section notes evidence of the world-wide relationship between rising insecurity and obesity. The article concludes with the reflection that should the argument of this article be correct, the obesity epidemic is symptomatic of a social mistake in modern capitalist society. In spite of the fact that the fundamental problem of material security has already been solved in rich countries, these societies remain institutionally locked into seeking maximum efficiency and economic growth, even though the consequences do not appear to be greater welfare (as measured by a subjective sense of happiness), but a rising level of insecurity and stress that is a root cause of the obesity epidemic.

\section{Dominant Explanations of the Obesity Epidemic}

The fact that people may over-eat and under-exercise is often attributed to evolution. It has been hypothesized that "thrifty" genes explain how our bodies maintain weight, protecting more strongly against weight loss than weight gain. ${ }^{8}$ Such genes would have been selected when humans were hunter-gathers, facing feastfamine cycles, and these genes would be "exceptionally efficient in the intake and/or utilization of food." When threatened with food scarcity, a preference for energy-dense foods (high sugar and/or fat content) represented an 
advantage in survival (Drewnowski 1995). ${ }^{9}$ Bodily fat would serve as a sort of fly-wheel, smoothing consumption of calories in a natural world where the availability of food was unstable. Presumably, below a certain threshold of physical activity, humans would become obese if able to access food regularly. Accordingly, the plenty and ease of modernity have resulted in epidemic obesity (Neel 1962: 354; Chakravarthy and Booth 2004). Thus to reverse obesity trends, people must exercise as much and eat as little as those in less comfortable times. According to this scenario, comfort is a curse.

While possible thrifty genes have been identified (Yang et. al. 2007: 56), they do not explain the very recent timing of the epidemic nor the social gradient; i.e., as noted above the wealthy have always had abundant food without suffering obesity, and in today's wealthy nations it is the least privileged who most suffer obesity.

Food scarcity in pre-modern times meant that carrying more weight was a signal of status, a conspicuous sign of economic well-being. ${ }^{10}$ Obesity, to the extent that it existed, was reserved for the upper class. Undernutrition among the working class, due in part to a low-fat diet, was seen as a fetter to industrial productivity in developed countries into the twentieth century (Caballero 2007). ${ }^{11}$

Today, the above-described social gradient - where weight and economic well-being are inversely related - indicates that obesity and its related health risks disproportionately affect those of lower socio-economic status. Not only is this true in the U.S. and other wealthy countries, but the same pattern is thought to be evolving in developing countries (McLaren 2007).

The dolce vita image of overweight has been replaced by stigma. The obese, in particular, are stigmatized. They eat too much food, eat too many unhealthy foods, and exert themselves too little ${ }^{12}$. The debauchery and laziness that have been attributed to the poor since the beginning of capitalism are now popularly attributed to the obese, who are, as noted earlier, disproportionately the poor. Victim-blaming is the norm, and as Caballero points out, “...political leaders still tend to regard obesity as a disorder of individual behavior, rather than highly conditioned by the socioeconomic environment" (2007: 4). However, victim-blaming explanations are rejected by most students of the phenomenon.

A popular account of the global obesity epidemic has been termed the "nutrition transition." Similar to the “epidemiological transition", whereby as countries develop, the leading cause of death shifts from infectious to noncommunicable diseases, the nutrition transition holds that as countries develop, technological innovation makes food plentiful and renders lifestyles sedentary, with the consequence that people eat too much and exercise too little. 
Obesity prevalence increases, resulting in a rise of obesity-related non-communicable diseases. Economic development therefore engenders obesity. The social gradient can be accounted for by inequities in access to healthy foods, gym memberships, expensive weight-loss programs and "fat farms," gastric bypass surgery, and health information. Presumably, extending these "luxury goods" to the less well-off would reduce the prevalence of obesity. More economic growth is part of the solution.

The dominant mainstream economic explanation of epidemic obesity conforms to the nutrition transition, also referred to as the "big two." If technological innovation lowers the price-per-calorie of food, then calorie intake is expected to increase. Calorie expenditure is expected to decrease if technological innovation is calorie-saving at work. In addition to exerting fewer calories at work, the opportunity cost of exerting them during leisure increases as incomes rise. Thus the theory predicts that people will take in more calories as calories become cheaper, spend fewer calories as innovation reduces the need for calorie expenditure, and consequently, gain weight, and eventually become obese. ${ }^{13}$

Empirical support for the mainstream economic explanation, however, is mixed. In support of the theory, as noted above, the prevalence of obesity among adults has been increasing for at least 100 years ${ }^{14}$ as technological progress has progressively reduced the relative costs of calories. ${ }^{15}$ The prevalence of obesity was relatively stable from 1960, when nationally representative data were first collected, until 1980, a period during which food prices increased faster than inflation. Then, between 1980 and 2000, when obesity reached epidemic proportions, food prices fell 14 percent relative to the inflation rate (Finkelstein et. al. 2005: 244). However, there is counter evidence that while the price per calorie was "roughly constant" between 1993 and 2005, the prevalence of obesity dramatically increased (Burke and Heiland 2006). It is also noteworthy that whereas the prevalence of obesity has been increasing, spending on food as a percentage of household income has been declining (Drewnowski and Specter 2004: 6). Philipson notes that "existing evidence seems to indicate that the effect of income on caloric intake is highly inelastic at the levels of income observed in rich countries" (2001:2).

Experimental studies also provide little support for the mainstream explanation. A number of studies have been carried out to test the usefulness of financial incentives for reducing weight. A "systematic review" of these studies "showed no significant effect of use of financial incentives on weight loss or maintenance at 12 months and 18 months" (Paul-Ebhohimhen and Avenell 2008: 355). 
Evidence on the calorie-expenditure side is also mixed. It is true that as the work week shortened and work became less-calorie intensive in the U.S. over the past century, the prevalence of obesity increased. However, between 1960 and 1980 when the prevalence of obesity stabilized, there was an eight percent decline in the number of workers (from 35 to 27 percent) in the physically-demanding goods-producing industries, which matches the decline from 27 to 19 percent during the two following decades when the prevalence of obesity exploded (Finkelstein 2005: 241). Further, Cutler, Glaeser, and Shapiro (2003) estimate that whereas energy expenditure declined between 1965 and 1975, it has since been stable. Other contributors to decreased physical activity, such as televisions and automobiles, also became far more prevalent between 1960 and 1980. Yet no corresponding increase in obesity was observed until after 1980. The biggest increase in watching television -- 40 minutes daily occurred between 1965 and 1975 (102). The replacement of walking and public transportation by automobile commuting "had largely run its course by 1980" (103).

Many of the most spectacular increases in labor-saving devices in the household also occurred during these decades when obesity was stable. For instance, Finkelstein et. al. point out that "the portion of homes with washing machines and dishwashers rose from 55\% to $77 \%$ and from $7 \%$ to $43 \%$, between 1960 and 1979 , but only slightly further to $79 \%$ and $54 \%$, respectively, by $2001 "$ (2005: 241). They also note evidence that leisure time has become more active since the obesity epidemic became virulent after 1980. Cutler, Glaeser and Shapiro (2003) claim that "The available evidence suggests that calories expended have not changed significantly since 1980 [when the epidemic began]" (2003: 93; see also Philipson and Posner 1999).

Although there is no doubt that technological progress established the conditions in which widespread obesity could occur, it does not explain it. Besides not accounting well for the empirical evidence, there are other reasons to be less than satisfied with the mainstream economic explanation. The only physiology employed is calorie arithmetic. While it is true that weight gain occurs because of a positive calorie imbalance (calorie intake exceeding expenditure over some period of time), this is a mere consequence of arithmetic or, at best, thermodynamic law (Wells 1998).

At the level of psychology, the explanatory framework of mainstream economics is built upon the rational choice model, according to which the behavior of economic actors can best be understood as the consequence of rational decision making. ${ }^{16}$ As Cutler et. al. put it, "The standard model of consumption involves rational individuals who decide how much to consume on the basis of price and income, fully accounting for the future 
health consequences of their actions" (2003: 112). In fact, as Philipson notes, "In a rational choice model... there is no such thing as being 'overweight'. Weight is the result of personal choices along such dimensions as occupation, leisure time activity, or inactivity, residence, and of course, food intake" (2001: 1). But how could individuals rationally decide to take in more calories than they expend to the point of becoming overweight or obese, given the powerful stigma attached to being much overweight, and especially obese (Puhl and Brownell 2001), ${ }^{17}$ not to mention the very serious health consequences? How can the rational choice model make sense of the fact that whereas prevalence of obesity is greater among women than men, studies show, as Philipson points out "a greater negative correlation between earnings and being overweight for women than for men?" (2001: 4).

Obviously, the sum total of decisions that result in obesity cannot reasonably be seen as rational. ${ }^{18}$ True, an individual does decide whether to pop another Twinkie. But is it useful in an explanatory sense to view this decision as rational? This model ignores any social factors that might influence individual decision making. It takes preferences as given. ${ }^{19}$ This model appears too simplistic to account for behavior that is clearly not rational in terms of the individual's self interest. ${ }^{20}$

The hypothesis explored in this article for clarifying the obesity epidemic is that it is due in part to heightened insecurity and stress in an environment affording ready availability of high-fat and high-sugar foods. ${ }^{21}$ Thus, it goes beyond the existing environmental hypotheses that Drewnowski and Specter list as "availability of snacks, fast foods, and soft drinks; the presence of vending machines in schools; and the phenomenon of 'supersizing' of fast foods eaten outside the home" (2004:13). The hypothesis of this article is grounded in the assumption that human behavior is significantly influenced by the social environment. It claims that preferences are at least in part endogenous - to some extent, socially created. Preferences are a consequence of both our genetic heritage and our cultural conditioning. This article rejects the assumption that humans can usefully be assumed always to behave rationally. ${ }^{22}$ It seeks in socio-economic change part of the explanation for the obesity epidemic.

The following section surveys a broad body of recent research that is strongly supportive of a relationship between insecurity, stress and obesity.

\section{Insecurity, Stress, and Obesity}

Threats to security are not, of course, new. Insecurity has been humanity's constant companion. Such threats came principally from predators, including other humans. Threats also come in the form of geo-physical and climatic events, many compromising an inadequate supply of food. ${ }^{23}$ Putting on weight - banking calories - is a 
'natural' response to insecurity, a genetic trigger selected during the course of evolution. When sustenance, lifeand-limb, or social positions were threatened, favoring fat-rich morsels and banking energy in the form of fat reserves would have been adaptive. In the struggle for subsistence, fat reserves would be advantageous when threatened by nutritional scarcity or uncertainty. Fat is fuel, insulation, armor, and important for sexual selection and reproduction (Pond 1998). ${ }^{24}$ Insecurity would be most extreme during crises caused by inadequate hunting and gathering resources, poor harvests, or war. However, the resulting privation meant severe food shortage, rendering an obesity response impossible.

Humans, like other animals, exhibit a "fight or flight" response to threats such as aggression. When threatened, emergency mobilization to enhance survival potential results in energy being redirected to muscles and mind. Stress hormones known as glucocorticoids, principally cortisol, increase glucose in the bloodstream. Energyburning activities like feeding and digestion are temporarily suppressed. ${ }^{25}$ Because these and the other fight-or-flight reactions (including increased heart rate and blood pressure) increased survival chances, they were selected during evolution (Kyrou et. al. 2006). Thus intense and temporary stress appears to suppress appetite. However, threats can be immediate or anticipated, real or imagined, and vary in intensity and duration.

What happens if a threat cannot be faced or escaped, if stress is unmitigated or chronic as is so frequently the case in modern industrial society? Medical research has found that chronic stress can be damaging and deadly. Kyrou, et. al., for instance, note that “...chronic stress can be defined as a pathologic state of prolonged threat to homeostasis by persistent or frequently repeated stressors and is considered a significant contributing factor in pathophysiology of manifestations that characterize a wide range of diseases and syndromes" (2006: 78). Miller et. al. point out that "Of the 10 leading causes of death, stress has been directly implicated in 4 (heart disease, stroke, musculoskeletal disorders or injuries, and suicide/homicide) and indirectly in 3 (cancer, chronic liver disease, and lung disorders like chronic bronchitis and emphysema)" (2002: 5). A considerable body of evidence that will be surveyed below shows that obesity, which is causally related to some of these diseases also results from chronic stress which maintains high levels of cortisol secretion.

\section{Laboratory Studies of Animals}

In laboratory studies of animals, where confounding factors can be controlled, stress prompts weight gain, especially abdominal fat, when high-fat, high-sugar food is available. Whereas high levels of stress induces reduced food intake (hypophagia), lower levels induce increases in food intake (hperphagia) (Kivimäki et. al. 2006: 985). 
However, the availability of calorie-dense foods influences the food-intake responses to stress. For instance, a recent study of mice (Kuo et. al. 2007) suggests that not all stress results in weight gain and that the availability of high-fat and high-sugar foods is important. When subjected to chronic stress - standing in a puddle of ice-cold water ("cold") or exposured to an aggressive mouse ("aggression") for one hour a day for two weeks—and given a high-fat, high-sugar (“American”) diet, mice gained about twice as much abdominal fat as unstressed mice fed the same diet. Neither chronic stress nor the American diet by itself resulted in much weight gain. Indeed, stressed mice fed standard chow actually lost weight. In addition to the type of food, stress-intensity was also important to this result. Mild chronic stress — standing on a post above room-temperature water ("water avoidance") or being stuck in a tube ("restraint") for an hour a day for two weeks - did not produce the same effects as cold or aggression.

This study of mice suggests that weight gain from a high-fat, high-sugar diet is exacerbated by intense, chronic stress. Weight gain in the form of abdominal fat tends to be much more than expected based on such a diet alone. The obesity result when the diet is accompanied by stress fits an evolutionary model. When threatened by cold or aggression, fat accumulation was selected to provide fuel, insulation, and armor. Moreover, it is likely that intense, chronic stress encourages choosing such a diet. Not only are fatty and sweet foods pleasurable, they also appear to act as calming opiates. Gibson notes that "in animals and human infants, the ingestion of sweet and fatty foods, including milk, alleviates crying and other behavioural signs of distress" (2006: 55). This is supported by Dallman et. al. (2003), who have found that eating high-fat and other "comfort" foods helps in reducing biological stress system activities and negative emotions resulting from stress.

\section{Human Studies}

Humans who eat more when stressed are frequently organized into three categories: "Restrained" eaters, “emotional" eaters, and high cortisol reactors. Restrained eaters consciously restrict food in order to control body weight. In a review of studies of women, Greeno and Wing (1994) conclude that being a restrained eater is the best predictor of eating more when stressed. Stress may override the restraint by "restrained" eaters. That is, when stress is believed to be uncontrollable, cognitive control over food choice tends to be inhibited (Alonso-Alonso and Pascual-Leone 2007). Alternatively, stress-induced eating may “mask” stress. Eating may "diminish the distress, presumably via central opiods" (Björntorp 2001: 80). Or, eating itself can be blamed, instead of the true, and possibly uncontrollable, source. Lack of control over the source is therefore masked. (Polivy and Hearmn 1999). 
Emotional eaters are those who have "short-term affective responses to appraisals of particular stimuli, situations or events having reinforcing potential" (Gibson 2006: 54). In an experiment, 'stressed' and 'unstressed' subjects prepared to make a four-minute speech on a controversial topic or listened to an excerpt from Dylan Thomas' Under Milk Wood, respectively, before a buffet meal of sweet, salty, and bland high- and low-fat foods. The threat of public speaking did result in higher blood pressure and self-reported anxious moods. Food intake quantity was similar between 'stressed' and 'unstressed' subjects, but 'stressed' 'emotional eaters' (self-reported, based on a questionnaire) ate more fatty and sweet foods, specifically cake and chocolate, and consumed more calories than 'stressed' 'non-emotional' eaters (as well as 'unstressed' 'emotional' eaters and 'unstressed' 'nonemotional' eaters) (Oliver, Wardle, and Gibson 2000).

Other experiments and studies that did not distinguish between emotional and non-emotional eaters still found that under stress individuals showed a preference for more calorie-dense foods. In an experiment (Zellner, et. al. 2006), female subjects were given 10 five-letter anagrams that, unknown to them, were either unsolvable or solvable. While attempting the anagrams, each subject had four bowls with M\&M's, chips, peanuts, and grapes, from which they could eat ad libitum. All subjects ate something. Afterwards, the subjects with the unsolvable anagrams reported significantly more stress than those with the solvable anagrams. The more self-reported stressed ate more M\& M's and fewer grapes compared to the 'unstressed' subjects. (Similar amounts of potato chips and peanuts were eaten by both groups).

A study of 11-to-13 year-old school children in London found greater stress to be associated with eating more snacks and fatty food, less fruit and vegetables, and greater likelihood of forgoing breakfast (Cartwright et. al. 2003). The stress of school examinations have also been found to increase overeating, especially for girls and for intake of fatty foods (Björntorp 2001: 80). In another study, French high school students ate significantly more fat on the day of an exam, compared to a control day without an exam (Micharud et. al. (1990). Lemeshow et. al. (2008) have found in a study of 4,264 girls (average age 15), that girls who rated themselves low in popularity were 69 percent more likely to gain about 11 excess pounds. A study of 971 Swedish students traced rapid weight gain to psychological stress (Mellbin 1989).

Eating behavior in the wake of the September 11, 2001 terrorist attacks supports these findings. After a few days, Americans were still reported to be stressed (Schuster, et. al. 2001). After a few weeks, sales of snack food had increased by more than 12 percent (Shell 2002). After a few months, eating habits had changed: 11 
percent reported snacking more post-9/11, 14 percent eating more comfort foods, and 20 percent eating more ice cream. Although 17.5 percent reported eating healthier (EuroRSCG Worldwide 2001), another earlier study found that when stressed, sweets and chocolate were more likely to be eaten, even by those who reported eating less overall (Oliver and Wardle 1999).

Dallman et. al. note that individuals with eating disorders such as bingeing or eating most of their calories during the night, report being chronically stressed and are obese. They typically indulge in comfort food that is high in fat and carbohydrates (2003: 11700). Finally, people typically self-report eating fatty and sweet snack foods when stressed.

High cortisone reactors secrete higher levels of cortisol when stressed. Studies suggest that women with this condition tend to eat more fatty and sweet foods and consume more calories after stress, both in a laboratory setting (Epel, et al. 2001) and in daily life (Newman, O’Connora, and Connera 2007). Björntorp reports that "Clinical experience clearly indicates that patients treated with corticosteroids have an increased, sometimes voracious appetite and frequently become obese, with a large fraction placed centrally" (2001: 78). Artificially elevating cortisol levels has been shown to increase appetite and feeding in cancer patients (Willox, et. al. 1984) and healthy men (Tataranni, et. al. 1996).

Various other studies also support the hypothesis of a link between stress and weight gain. Primary caregivers to a spouse with Alzheimer's disease -- compared to a control group of spouses, neither of whom were mentally or physically impaired -- had, for males, a higher BMI and, for females, more weight gain over a 15-18 month period (Vitaliano et. al.1996). Sexually abused children are more likely to become obese as adults (Gustafson and Sarwer 2004).

Stress-related weight gain might not, of course, be driven only by increased calorie consumption. Stress may also discourage exercise. A survey of working adults found that high self-reported stress was associated with a high-fat diet and low physical activity (Ng and Jeffery 2003). In another study (Smith, Baum, and Wing 2005), parents of a child diagnosed with cancer were more likely to have gained weight and to have gained more weight three months after the diagnosis, compared to parents of healthy children. The parents reported eating fewer calories as well as exercising less, suggesting that weight gain was driven by decreased physical activity.

Thus it would appear that although insecurity and stress do not always lead to weight gain, they very frequently do. This seems to be especially the case where there is ready availability of fat and sugary foods. 
But has there been an increase in insecurity and stress over the past three decades that could help explain the obesity epidemic? The next section turns to this question.

\section{Creative Destruction and Insecurity}

Over the past three decades, as state socialism first faltered, then self-destructed, proponents of a return to a more unbridled form of capitalism rediscovered the work of Joseph A. Schumpeter. What most caught their fancy was Schumpeter's convincing characterization of capitalism as a dynamic system of "Creative Destruction" -- a "process of industrial mutation...that incessantly revolutionizes the economic structure from within, incessantly destroying the old one, incessantly creating a new one. This process of Creative Destruction is the essential fact about capitalism" (1962: 83).

It is this process of creative destruction that has made capitalism the most dynamic, long-run, wealthcreating system that history has known. It has enabled those countries that have adopted capitalist institutions to achieve ever-rising material standards of life. It has also brought greater political democracy and greater freedom of self-determination to the overwhelming majority of those who live in these societies.

Schumpeter's understanding of the radical dynamism of capitalism was inspired by Marx. Like Marx, he knew well that this process of creative destruction destroys far more than the "economic structure." As Marx and Engels had put it almost a century earlier, under the regime of capitalism, "all that is solid melts into air." Not only are the processes of production and distribution of economic output constantly revolutionized, but all other domains of life are also continually transformed. Villages die as cities grow, the cohesion of families crumbles as individuals become more independent of traditional ties, and old ideas and values are delegitimized by growing science and new ideas and values more consistent with evolving social structures.

Nevertheless, although "all that is solid melts into air," the creative destruction begins in the economic domain and it is here that transformation is quickest and most dynamic. Much of this fast-paced dynamism is readily welcomed, especially the rising incomes, the ever-superior new products and the old ones at ever-lower prices. But part of the dynamism is harsh and painful, creating greater economic, social, and psychological insecurity. The obesity epidemic correlates with this latest and most robust period of creative destruction.

No indices have been developed for directly measuring the trends of insecurity and stress. Nevertheless, an examination of change and tumult in a number of domains of life over the past three decades strongly suggests that insecurity and stress have indeed increased. 
Indication that this is true are the measurements found in an "Index of Social Health of the United States" constructed by Miringoff and Opdyke (2008). Their index is intended to provide a composite measure of social health or well being. Based on a scale of 100, it has declined from 69.6 in 1973 to 53.2 in 2005, a drop of 23.6 percent (237).

A few of the following are included in their index: Although wealth and income have grown significantly, their distribution has become increasingly unequal, with most gains going to the very rich. Average weekly earnings (in 1982 dollars) declined from $\$ 331.39$ in 1973 to $\$ 275.93$ in 2005, greatly lagging behind productivity gains (Miringoff and Opdyke 2008: 226). The housing affordability index declined from 147.3 in 1970 to 111.8 in 2005 (233). ${ }^{26}$ The child abuse rate (per 1,000 population ages 0-18) has increased from 10.1 in 1976 to 48.3 in 2005 (221). Violent crime rates per 100,000 population were 369.5 in 1970, rising to a high of 758.2 in 1991, and then declining to 469.2 in 2005 (230).

In his recent book, The Great Risk Shift, Jacob Hacker documents "how a myriad of risks that were once managed and pooled by government and private corporations have been shifted onto workers and their families and how this has created both real hardship for millions and growing anxiety for millions more" (2006:21). For instance, a quarter century ago, 83 percent of medium and large firms provided their employees with defined-benefit pensions whereby upon retirement, they would receive guaranteed monthly incomes for life. Today, fewer than a third of firms continue to offer these pension plans, having substituted defined-contribution plans in their place. Not only do these plans provide no assurance of future returns, they put the risk entirely upon the employee (Hacker 2006: 14). Further, many young people no longer believe that Social Security will be there for them when they retire.

Surveys and polls report that many Americans feel stressed. For instance, in a 2006 representative sample of American adults over 18 years of age, almost half (47 percent) reported being concerned about the amount of stress in their lives. ${ }^{27}$ It found "that people experiencing stress are more likely to report hypertension, anxiety, depression or obesity" (Stambor 2006: 28).

An ERG poll asked respondents to select as more true one of the following statements: "Most people today face increasing uncertainty about employment, with stagnant income, paying more for health care, taxes, and retirement, while those at the top have booming incomes and lower taxes."

or 
"Our economy faces ups and downs, but most people can expect to better themselves, see rising incomes, find good jobs and provide economic security for their families."

64 percent chose the first statement; 32 percent the second (Kusnet, et. al. 2006: 23).

Evidence for growing insecurity in various life-domains is provided below. Although this evidence strongly suggests that insecurity and stress have increased over the past three decades and have causally contributed to the obesity epidemic, people have not been equally impacted. Not everyone has experienced the same increased levels of insecurity and stress. Further, whereas stress causes some people to eat more, it causes others to eat less (Kivimäki et. al. 2006). ${ }^{28}$ Nevertheless, the evidence clearly supports the hypothesis that increased insecurity and stress have contributed to the obesity epidemic.

\section{Heightened Job and Income Insecurity}

The domain of work appears to be critical to human well-being and happiness. As Robert Lane has put it, "It is in work, not in consumption and, as research reports show, not even in leisure, where most people engage in the activities that they find most satisfying, where they learn to cope with their human and natural environments, and where they learn about themselves" (1991: 235). Having a job - working - is very important for self-identity, for certification of possessing social importance. Indeed, so important does work appear to be that a World Values Survey found that "only 22 percent of respondents agreed that a job is just a way of earning money, and 63 percent said that they would enjoy having a paying job even if they did not need the money" (Alesina, Glaeser, and Sacerdote 2002: 239).

Given this centrality of work to human well-being, it is to be expected that threats to its security or conditions that compromise its quality would be stressful. Research finds this to be true, and that such stress often leads to weight gain.

Although no widely-agreed upon way to measure job insecurity exists, ${ }^{29}$ there is evidence that job security has eroded over the past several decades. The average unemployment spell has gone from 12 to 16 weeks since the late 1970s. Over the past 25 years, fears of losing employment have substantially increased. A poll conducted in 1982, when unemployment reached 10 percent, found that 12 percent of workers were "frequently concerned about being laid off." In 1996, with unemployment at only about five percent, 46 percent expressed the same concern. In 2005, again with unemployment at about five percent, over 30 percent expressed this concern (Hacker 2006: 18). 
Other surveys confirm this increase in anxiety concerning job security (Herzenberg, Alci, and Wial 1998; Mishel, Berstein, and Schmitt 1999).

Job insecurity almost always means income insecurity (Davis, Smith, and Marsten 2000). This is especially the case in the U.S. The unemployment insurance average replacement ratio in the U.S. for qualifying workers is about 38 percent. However, in the mid-1990s only 44 percent of unemployed workers qualified for benefits, and about one quarter of these failed to file for benefits (Anderson and Meyer 1997). By 2007, only 37 percent of unemployed workers qualified for benefits (Center for American Progress Action Fund 2008). These benefits generally expire after 26 weeks.

The probability of an average family experiencing an income drop of half or more has jumped from 7 to 17 percent since the early 1970s (www.hamiltonproject.org). In the mid-1990s, income instability was five times greater than in the early 1970s, and although it declined somewhat in the boom of the late 1990s, it shot up again in the early years of the new century (Hacker 2006: 27). The rise in income insecurity has been true for highly educated workers as well as those with little education (28). Further, when households experience falls in income, they are much greater than before, rising from about 25 percent of income in the early 1970 s to about 40 percent in the late 1990s (31). One consequence of this is that almost half of all Americans between age 25 and 75 will experience a year in poverty (as officially defined) and over half of all American children spend a year in poverty by the time they are 18 (32-33). Whereas in the late 1960 s, workers in their $40 \mathrm{~s}$ - their peak-income-earning years had about a 13 percent chance of falling into poverty, in the 1990s their risk was 36 percent (33).

Rising financial insecurity is also evident in the fact that whereas fewer than 290,000 households filed for personal bankruptcy in 1980, more than two million did so in 2005. Although home ownership has increased since the early 1970s, mortgage foreclosures have increase fivefold (Hacker 2006: 13).

\section{Job Insecurity, Stress, and Obesity}

Job insecurity is understandably stressful and a broad body of evidence strongly suggests that this stress increases the incidence of obesity. For instance, weight gain, seemingly related to stress, has been found among British civil servants in the widely-known Whitehall II Study. Thatcherism provided a natural experiment on the health effects of job insecurity when a department of white-collar employees was privatized (Ferrie et. al. 1998). Compared to other departments that remained within the government, these employees (both males and females) had a significant increase in mean BMI over a roughly five-year period, from before rumors of a sale until the transfer of 
ownership. The increase could not be explained by changes in exercise, smoking, or alcohol use (unfortunately, changes in diet were not considered).

Another study by Brunner et. al. (2007) finds that self-reported "work stress"-- job strain and low social support at work -- to be a strong predictor of obesity, again, among British civil servants in the Whitehall II Study. Employees who experienced "chronic work stress"-- work stress reported during at least three of the five study phases over a 14-year period -- had a 73 percent higher risk of being obese compared to those without work stress, controlling for age, sex, and employment grade. Reporting work stress during just one or two of the study phases was associated with a 17 percent and 24 percent higher risk, respectively. Even after controlling for behavior (i.e., $\operatorname{diet}^{30}$, exercise, smoking, and alcohol use), employees with chronic work stress still had about a 50 percent higher risk of being obese and a 61 percent higher risk of central obesity (defined for adult males and females as a waist circumference of 40 and 30 inches or greater). Brunner et. al. conclude that there is "firm evidence that high psychological workload, together with lack of social support at work, acts as a causal factor for obesity" (2007: 833).

Another study of 6,057 British male workers who had been fully employed over the previous five years, found that five years later the 1,645 men who had suffered some unemployment gained more weight than those who were continuously employed (Morris et al 1992). A study of 1,980 Danish men also found that employment insecurity significantly increased the likelihood of weight gain (Hannerz et al 2004). Laitinen et al (2002) found in a sample study of 2,359 31-year-old Finish men that being single or divorced, suffering a long history of unemployment, or having a low level of occupational education predicted self-reported stress-related eating. Selfreported stress-related eating among 2,791 Finish women in this same study correlated with "a lack of emotional support."

The fact that unemployment and its threat are greatest for the least privileged in society may help explain why overweight and obesity are high in these families. Research by Christopher Whelan concludes, not unexpectedly, that "the major factors leading those located in the lower social classes to experience higher levels of psychological distress are their greater exposure to unemployment and economic deprivation; in particular, exposure to deprivation of an extreme kind which involves the enforced absence of necessities such as food, clothing, and heat" (1994: 58). Further, in a study of social support for unemployed workers, Atkinson, Liem, and Liem report 
that "unemployed blue-collar men experienced somewhat more decline in support than white-collar men" (1986: 324).

The pecuniary and psychological costs of unemployment are disproportionately heavy burdens to the least well-off, those who lack access to private institutions such as banks and insurance companies that are available to the more fortunate for helping out with life's uncertainties. Instead, they must look to relatives and state agencies that serve marginalized persons (Kieselbach 2003). Accordingly, Edward Wolff's research has found that the poorest 20 percent of the population has no financial resources upon which to fall back, meaning that sudden unemployment for these families entails extreme hardship. Those in the second poorest quintile have financial resources to last only slightly more than half a month at 125 percent of the poverty level. Even those in the middle quintile do not have resources to last for more than two months at this level (1998). Thus the threat of unemployment places considerable stress on 60 percent of the population. ${ }^{31}$

Unemployment among parents appears to be stressful for children. Adolescent boys with unemployed parents were less likely to be confident about the future or to be independent and hopeful than were boys from families that "were not plagued with unemployment" (Storm 2003: 399). Further, adolescents who attempt suicide are more likely than other adolescents to have an unemployed father (Storm 2003: 401).

\section{Stressful Workplaces and Obesity}

"Job strain"- when job demands are high and control over work is low—has been found to be stressful. Björntorp notes that "A considerable number of studies have shown that various strains during work, particularly when demands are larger than decision latitude, and in situations with monotonous type of work and lack of control, are followed by elevated secretion of cortisol...[which] is followed by visceral fat accumulation" (2001: 75). He also notes that a study of workers during an ordinary working day revealed that, "being happy was followed by low cortisols and feeling miserable the opposite" (2001: 75).

Kivimäki et. al. (2006) find that job strain is able to predict increased BMI (at follow-up, an average of 5 years later) for men who were heaviest initially (i.e., in the highest BMI quintile, $>27 \mathrm{~kg} / \mathrm{m}^{2}$ ). However, they also found that job strain predicts decreased BMI for men who were initially the lightest (i.e., in the lowest BMI quintile, $<22 \mathrm{~kg} / \mathrm{m}^{2}$ ). For those of an intermediate weight initially (BMI of 22 to $27 \mathrm{~kg} / \mathrm{m}^{2}$ ), there was no significant association with BMI change. It therefore appears that job strain made the heaviest heavier, the lightest lighter, and 
produced mixed results for those of an intermediate weight. Among women, however, job strain and increased BMI were weakly associated. ${ }^{32}$

A number of factors might account for these varied responses. Obviously, mean BMI may obscure stressrelated, bidirectional weight change among individuals. Studies of identical twins reared apart suggest variation in genetic predisposition to gain weight (Stunkard et. al. 1991). As Hill and Peters put it, "Genetic make-up... plays a role in that it determines the strength of an individual's physiological defense against gaining and maintaining an obese body fat level" (1998: 1371). Björntorp notes that "Obviously, factors such as personality characteristics, competence, education, and social status are heavily involved in the risk of ending up in a situation of 'stress' and psychological insufficiency" (2001: 74). Accordingly, there may be variation in vulnerability to gain weight when experiencing increased job stress. The relationship between stress and weight gain may have to do with the total amount of life stress that the individual suffers. Modern humans live in multiple domains: households, workplaces, neighborhoods, social networks, a political world, and a macroeconomic world. Stress in any particular domain might then be expected to impact individuals differently. As noted in the study above, weight gain when stressed correlated with the individual's weight condition at the outset. Those who were heavier at the outset may have been heavier due to greater stress and a life-style that included greater daily availability of high-fat and high-sugar foods. Unfortunately, these studies did not control for these factors. Nevertheless, Brunner et. al. find that "Employees experiencing chronic work stress have approximately 50 percent higher odds of obesity compared with those without work stress, after taking into account socioeconomic position and variation in adverse health behaviors" (2007: 835).

What threats in the workplace might engender uncontrollable or intense chronic stress? Many humans feel threatened at work, especially by superiors who can fire them, damage their careers, or boss them about, often in a seemingly arbitrary manner. Indeed, most must bow, often unquestioningly, to the authority of firms' owners or agents. Thus, it is hardly surprising that levels of cortisol tend to be higher on weekdays than weekend days (Adam and Epel 2007: 455). The Whitehall Studies revealed central abdominal fat to be strongly associated with occupational hierarchy (Wallace and Wallace 2005: 364). Roughly half of an adult's waking life is spent at work. A recent study finds that confluent threats of high demands, low control, and low social support at work appear to be particularly stressful. 
Animal studies support the relationship between subordination and a tendency to gain excess abdominal fat. A study of the effect of aggression on mice also finds that social subordination is particularly threatening. Some animals, when stressed, exhibit a "defeat reaction," especially during social subordination, instead of the typical fight-or-flight response. Subordinate monkeys appear fearful and depressed, have higher levels of cortisol, and gain excess abdominal fat (Bjorntorp, 2001: 74). Sapolsky (2005) finds that for both mice and female rhesus monkeys, whose social hierarchies are stable and maintained through psychological intimidation rather than physical aggression, subordinates experience greater stress than dominates. Physiologically, subordinates exhibit higher levels of stress hormones (glucocorticoids) than dominates. Subordinate willow tit birds have more body fat when food is not scarce, even though they must expend more energy in acquiring food (Ekman and Lilliendahl 1993).

Animal studies have also found that serotonin levels positively correlate with social rank. Indeed, when an individual rises to "alpha" status, serotonin rises, and is in turn lowered when that rank is lost (Raleigh et al 1991). Serotonin appears to induce weight loss. Pigeons that have had serotonin directly injected into their brain lose appetite, eat less, and subsequently weight (Steffens et al. 1997). Anti-depression drugs known as selective serotonin reuptake inhibitors have been found to induce weight loss in obese patients (Halford et al 2005).

Occupational hierarchy may help explain social gradient obesity, since lower-income individual, minorities, and women typically have less control over their workplaces. It has also been found that obese women are employed mostly in low-paying occupations and infrequently found in high-paying managerial, professional, or technical jobs (Pagan and Davilla 1997).

\section{Growing Inequality and Status Insecurity}

There is reason to believe that significant inequality produces social environments that are more stressful.

\section{As R.G. Wilkinson puts it,}

"Inequality promotes [survival] strategies that are more self-interested, less affiliative, often highly antisocial, more stressful and likely to give rise to higher levels of violence, poorer community relations, and worse health. In contrast, the less unequal societies tend to be much more affiliative, less violent, more supportive and inclusive, and marked by better health....more unequal societies tend to have higher rates of violent crime and homicide, and ...people living in them feel more hostility, are less likely to be involved in community life, and are much less likely to trust each other; in short, they have lower levels of social capital" (2005: 24). 
It is thus not surprising in terms of this article's thesis that across the developed world, a country's degree of income inequality has been found to be positively and statistically significantly associated with the prevalence of obesity among both men and women. For instance, Pickett et. al. report that "the USA had the steepest social gradient in obesity and the greatest income inequality, and Sweden the smallest of each." Moreover, these "findings are consistent with studies within the USA, which have shown associations between state level income inequality and abdominal weight gain in men, odds of sedentary lifestyles among both men and women and higher BMI among women" (2005 673; 672).

This relationship between inequality and obesity also appears to hold true for rising inequality. Note, for instance, that among rich nations, the U.S. and Great Britain have experienced the greatest increase in inequality since $1980^{33}$ and the greatest increase in the prevalence of obesity.

Rising inequality makes each income level below the top feel relatively less well off, thereby increasing pressure to maintain social status. Because social status is important for self-esteem, which John Rawls has suggested is "perhaps the most important primary good" such that without it nothing else has much value (1971: 440), increasing insecurity concerning status can be expected to be stressful. Consequently, an increase in inequality might be expected to prompt households to potentially respond in three manners, with the accompanying consequences: People might consume more, forcing them to save less, thereby potentially making them more insecure and stressful about their financial futures. Or to increase consumption, they might become more indebted, also increasing their sense of financial insecurity. Or in their struggle to maintain status, they might increase the hours they work to enable them to increase their consumption levels, with the result that they feel increasing time pressure (Bowles and Park 2005). Evidence indicates that U.S. households have done all three. Saving rates have fallen dramatically over the past couple of decades, from about 10 percent in 1980 to less than zero in 2005 and 2006. Debt-to-income ratios more than doubled from 0.45 in 1984 to 1.19 in 2004. In 1973, households owned 68.3 percent of the equity in their homes. By 2004, it had fallen to 55 percent (Hacker 2006: 98). And between 1970 and 2002 work hours per capita rose 20 percent in the U.S. (Wisman 2009).

In a recent study, Gundersen et. al. produced a cumulative stress index and found that in food-secure lowincome households, a mother's stress increases the probability that a young child, aged three to 10 , will be overweight or obese. The study notes that "low-income families may have difficulty dealing with stressors, because they may not have adequate resources to cope with them" (2008: 531). 
Educational attainment varies directly with income level and the prevalence of obesity varies inversely with years of schooling (Drewnowski and Specter 2004). Rosin claims that this is due to the fact that the more educated possess more health knowledge (2008:15). Undoubtedly, more education increases knowledge of health issues. However, in conformity with the hypothesis developed here, an alternative link between education and obesity may be that individuals with more education are more likely to have greater control over their lives and therefore be

better able to shield themselves from insecurity and stress. ${ }^{34}$ Moreover, as Philipson points out, "Because people know more about the effects of over-weight today than they did in previous times, yet obesity has grown, lack of knowledge is an unlikely explanation for that growth" (2001: 4). It is also notable that although food labeling became mandatory in 1990 in the U.S., the obesity epidemic continued to worsen.

At the very bottom of the social gradient in the U.S., 11.2 percent of households were reported by the USDA in 2003 to be "food insecure" and thereby suffer hunger due to inadequate resources (Nord et. al. 2004). Tanumihardjo, et al point out that "Food insecurity is complex, and the paradox is that not only can it lead to undernutrition and recurring hunger, but also to overnutrition, which can lead to overweight and obesity... [and indeed] one of the overwhelming outcomes of food insecurity is obesity" (2007: 1966; 1968). A study by the Partnership for America's Economic Success found that young children in families that have suffered food insecurity are three to four times more likely to be obese than children in food-sufficient families (Murphy 2008). The seeming solution to the paradox is that is that the stress of food insecurity increases the prevalence of obesity.

\section{Soaring Health Care Costs}

Soaring health care costs have also added to the general level of stress. Average cost of family health insurance for 2007 was $\$ 12,106$, almost equal to the minimum wage for a full-time worker of $\$ 12,168$. Since the early 1980s, medical care costs have increased by 251 percent, whereas median family income has risen by 147 percent, and the consumer price index by106 percent (National Center for Public Policy and Higher Education, reported in Kinzie 2008: A6). More recently, since 2001, premiums for family coverage have gone up 78 percent, while wages have risen 19 percent and consumer prices 17 percent. The percent of Americans without health insurance increased from 10.9 percent in 1976 to 15.9 percent in 2005 (Miringoff and Opdycke 2008: 138). The percentage of people covered by employer-based health insurance plans in medium and large firms fell from 90 percent in 1988 to 65 percent; in small firms it fell from 69 to 43 percent (Miringoff and Opdycke 2008: 139). Not unexpectedly, those at greatest risk of being uninsured are Hispanics, African Americans, and the poor generally. 
Out-of Pocket health costs as a percent of income spent on health care among those 65 and older increased from 11.1 percent in 1973 to 16.1 percent in 2005 (229).

\section{Declining Social Capital}

In a much-discussed 1995 article, Robert Putnam found that participation in local groups had been falling over recent decades (Putnam 1995). He termed the consequence a loss of social capital. ${ }^{35}$ Social capital provides a sense of community and thus serves as a source of psychological security. Holtgrave and Crosby (2006) have found some evidence that social capital lowers the risk of obesity.

Presumably, working against social capital formation is the fact that working longer hours, and often spending more time commuting means individuals have less free time. The stress of their time demands may result in sleep deprivation, which a number of studies have linked to abdominal fat accumulation (Spiegel et. al. 1999; American Academy of Sleep Medicine 2008). Sleep deprivation has been shown to augment hunger and appetite. Sleep deprivation also produces hyperphagia in animals (Keith et. al. 2006: 1587).

Irvin reports that growing inequality also reduces social capital: "Where there is more income inequality, poorer people are more likely to feel out of place participating in community groups, more likely to feel ill at ease and to think that they will make fools of themselves and be looked down upon. Equally, there is a clear link between growing inequality and the rise of fundamentalist religious communities, which provide a replacement for traditional support networks" (2007: 15).

\section{Neighborhoods}

Neighborhoods are important components of an individual's environments. The extent to which they offer security can be expected to vary with the general socio-economic status of its residents. This may be one of the reasons why degrees of inequality and obesity appear to be related.

Over the past quarter century, neighborhoods have become more segregated in terms of class. Because poorer neighborhoods are typically plagued by more broken families, higher unemployment, and greater crime, it might be expected that they would be more stressful and that their residents would consequently suffer greater obesity. Research supports this.

A study of the Seattle metropolitan area found that the prevalence of obesity in a zip-code is negatively associated with the median residential property value. A lower median property value is associated with a more obese zip code (Drewnowski et. al. 2007). 
A trial program suggests that moving out of poor neighborhoods may reduce stress and the incidence of obesity (Orr et. al. 2003). Impoverished families, living in inner cities with very high poverty rates (i.e., more than 40 percent of the census tract below the poverty level), were given vouchers to move to low-poverty neighborhoods (required to have fewer than 10 percent below the poverty line). Almost half (47 percent) of the families used these vouchers. During an evaluation over four years later, the adults reported feeling safer at night and having less stress. The incidence of obesity among adults had been lowered by 20 percent.

Lumeng et. al. (2006), have found that children (four to seven years of age) are four times more likely to be overweight if they live in a neighborhood that their parents ranked in the bottom quarter of safety as opposed to those whose parent's ratings placed them in the top quarter. ${ }^{36}$

\section{Rising Prison Populations}

The U.S. prison population has soared. According to the U.S. Census Bureau, the number of people incarcerated had remained fairly stable until 1973. Indeed, it even fell for a brief period during the 1960s.

However, there was a 380 percent increase in the number of people supervised by the Department of Justice between 1980 and 2006, from 1.8 million to 7.2 million (in 2006, 2.3 million were behind bars). 7.2 million represents about 3.2 percent of the adult population, or one in every 31 adults. With less than five percent of the world's population, the U.S. has almost a quarter of the world's prisoners. Insecurity and stress may be drivers of the criminality that led to difficulties with the law. Being in prison or parole is surely stressful, not only for the individuals, but their families and friends alike.

\section{Obesity as Self-reinforcing}

Being overweight, and especially being obese, can itself be expected to be stress-inducing in societies in which being fat is widely viewed as a personal failing. The obese are more likely than others in the population to suffer depression, and this is especially true where they themselves hold anti-fat beliefs (Friedman et. al. 2005). Carr and Friedman find "compelling evidence that obese persons are stigmatized and that this stigmatization transcends negative evaluations by others... [they] find that obese individuals perceived that they are the target of multiple forms of discrimination and that this discrimination has implications for their psychological well-being" (2005: 253). Carrying considerable excess weight may create a feed-back loop whereby stress in an environment of inexpensive foods high in sugar and fat leads to weight gain that is itself stressful, provoking a greater appetite for these foods and yet further weight gain. Gibson reports that "Intensity of negative moods (sad, ashamed, anxious, 
sleepy) increased with increasing energy density of the foods, and more so for overweight than normal weight women" (2006: 54).

\section{The 1960 - 1980 Anomaly}

As noted above, whereas the prevalence of obesity has been increasing for a century, it stabilized between 1960 and 1980. Why? During these two decades, creative destruction was more robust than ever before. Fast food restaurants were rapidly expanding. Advertising for "junk" food was exploding. Television viewing hours grew rapidly. ${ }^{37}$ People were driving more miles in automobiles and walking less. Women entered the workforce in record numbers. Adult smoking rates, which are inversely related to obesity, fell at about the same pace as in later years (Public Health Service 1996). ${ }^{38}$

A possible explanation is that the period up to the mid-1970s was one of exceptional optimism, especially among the young. For the first time in human history, generations were coming of age in the wealthy countries without fear of dire material privation. Robust economic growth, low unemployment, labor empowerment, and transcendence of fear of extreme privation set the conditions for extraordinary optimism that a better more just world was in the making. People increasingly believed that poverty, racism, sexism, and war could be eliminated. Inequality lessened between World War II and the mid-1970s. And feeling more secure, people felt freer to pursue the higher things in life. Worker productivity increased by an average of almost three percent per year between 1948 and 1973, meaning that real income approximately doubled during these 25 years, generally making children almost twice as well-off materially as their parents. This unprecedented affluence put people at ease. Not only could they be less strict with their children (the Spock generation), but they could also "lighten up" on themselves.

Sociologist Ronald Inglehart has found evidence that this extraordinary victory over the harshness of scarcity generated a shift from materialist to postmaterialist values, from "an overwhelming emphasis on material well-being and physical security toward greater emphasis on the quality of life." He defines postmaterialists as follows: "Postmaterialists, according to our reasoning, are Postmaterialists precisely because they take economic security for granted" (1990: 5; 238).

Public policies also promised greater security. A war on poverty was declared. Medicare and Medicaid provided greater security that old age and poverty would not preclude medical care. Social Security coverage was broadened to include the disabled, surviving spouses and dependent children. Better nutrition for the poor was promised by the creation of foodstamps. The poor were assisted with lodging through public housing and rent 
subsidies. Project Headstart offered pre-schooling assistance to poor children. Job training became more readily available to the poor under Job Corps. Between 1964 and 1979, a large number of national laws were enacted to provide people with greater security: 62 health and safety laws to protect workers and consumers, and 32 laws to protect the environment and regulate energy use. The most important resulting agencies were the Occupational Safety and Health Administration, the Consumer Product Safety Commission, the Mine Enforcement and Safety Administration, and the Environmental Protection Agency (Parenti 1999: 111).

This period of optimism and ease was, however, relatively short-lived. Two severe recessions -- 1973-75 and 1981-83, both, sequentially, the deepest since the Great Depression - combined with high inflation and weak economic growth (“stagflation”) and soaring energy prices, made people feel more insecure about their jobs and standards of living. In the 1973-75 recession, unemployment reached nine percent; in the 1981-82 recession, 10.8 percent. Intensified competition from expanding international trade and technological change increasingly put jobs at risk. The advent of AIDS created a terrifying new insecurity concerning sexual relationships. Inequality began increasing. The dollar lost its gold backing and the U.S. was defeated in Vietnam, leading pundits to write of the end of the American Century. The earlier sunny optimism faded. The historical struggle for material security was put back on track.

\section{A World Health Problem}

This article has focused primarily on the obesity epidemic in the U.S. because it is here that the epidemic is most severe and here that creative destruction and its consequences of insecurity and stress have generally been greatest. Obesity, however, has become a worldwide problem. Indeed, over a decade ago, it was ranked by the World Health Organization (WHO 1998) as one of the foremost 10 global health problems. Following the hypothesis of this article, this global explosion in obesity is likely due in part to rising insecurity and stress in a world in which food, especially fat and sweet food, is more readily available.

The world has been buffeted by an increasing pace of change over the past three decades. In the late 1970s, extremely low unemployment rates gave way to double-digit unemployment in most Western European nations, and during this same period, extended families and communities weakened considerably. Since then, obesity in Western Europe has taken on epidemic proportions.

The disintegration of the Soviet Union dramatically increased insecurity in Eastern Europe as unemployment soared and social support systems eroded. Since, obesity rates there have on average doubled, with 
the highest rates in Romania and the former strife-torn Yugoslavia (Spritzer 2004). The end of the Soviet Union also reduced barriers to the expansion of capitalism into practically every corner of the world, thereby more rapidly eroding traditional ways of life. The prevalence of obesity in China has also soared as the dramatic turn toward capitalist institutions has upset more traditional modes of life (Wu 2006). Ho and Chan report that "In Hong Kong China, increasing BMI was associated with a lower number of sleeping hours and increasing working hours, suggesting an intimate relationship between physical health and psychosocial stress ... with obesity as one of the major risk factors" (2008: 35). In a study of the Bhutias, a tribal people in the Himalayas, Sarkar and Mukhopadhyay (2007) found that those living in towns suffered more perceived psychosocial stress and consequently greater prevalence of obesity.

Further potential evidence of a link between insecurity, stress, and obesity is that of the seven nations in which obesity is greatest, five are Anglophonic (U.S., U.K., Australia, New Zealand, and Canada). The nonAnglophonic are Germany (number 3) and Iceland (number 5). Following upon the work of La Porta et. al. (1999), Cutler, Glaeser, and Shapiro point out that "Countries with a common law legal origin (the British model) are much less regulated than are countries with a civil law origin (the French model)... [and that] More regulated countries are 7 percent less obese than are less regulated countries" (2003: 111-112). Less regulated countries enable a more rapid disintegration of the security of traditional social institutions. Anglo-Saxon nations have more readily adopted laissez-faire approaches to their economies, which has generally entailed weaker safety nets and social support systems and hence greater insecurity. The prevalence of obesity in the U.K. is second only to that in the U.S. Yet in the U.K. it has increased faster, starting at a lower level. It is noteworthy that this occurred in the wake of the socalled Thachter revolution in which labor and social protections were shredded (Vlad 2003). Further, between 1984 and 1990, the Gini coefficient for the U.K. rose a striking 10 points, indicating a greater increase in inequality than in any other OECD country (Irvin 2007: 10).

The Reagan and Thatcher revolutions reinvigorated laissez-faire ideology that emphasized everyone's "freedom to choose," everyone's responsibility to look after themselves. But as sociologist Inge Røpke points out, it feels very stressful and frustrating to be responsible for one's own life, and consumption is a source of anxiety and uncertainty, because the handling of choice is so critical.... a wrong choice can be self-destructive" (1999: 411).

\section{Final Reflection}


The dominant account of the obesity epidemic is that material affluence has allowed us to over-eat and under-exercise and that our evolutionary heritage obliges us to do so. Although environmental factors such as advertising, availability of high-fat and high-sugar foods, etc., may be contributory, the fundamental cause of the problem is our inherited predisposition toward gluttony and sloth. The poor are fatter because, unlike the rich, they lack self-control, eat more less-expensive high-energy dense foods, and lack access to gym memberships. The prescription is we must all become richer so as to afford healthier foods and exercise opportunities. What is striking about this interpretation is that Americans are fat because they have become so rich, but poor Americans are fat because they are not rich enough.

This article has argued, instead, that the obesity epidemic is traceable in part to increasing insecurity and stress in an environment in which there is ever-greater availability of fat and sugary foods. The social gradient of obesity is due to a social gradient of insecurity. The logic of evolution as well as a growing number of studies suggests that insecurity and stress enhance appetite for fatty and sweet foods, with weight gain resulting. The availability of such foods is thus in good part demand-driven, a consequence of rising insecurity and stress stemming from capitalism's ever-more robust creative-destruction. Consequently the prescription that we need more economic growth to become richer, even if this entails greater insecurity and stress is bad medicine.

It is only in the last few centuries that sustainable economic growth has been recognized as possible, generating what might be called a material progress vision. Central to this vision is the presumption that economic growth will make possible the good and just society. Therefore, society should consider economic growth as its highest priority. This has promoted a somewhat exclusive preoccupation with material progress as the key to improved human welfare. Largely neglected are such essential components of human welfare as more creative and fulfilling work, greater equality in the distribution of opportunity, income and wealth, richer and more supportive communities, and more time for family, friends, and reflection, all of which can be treated as subsidiary issues because maximum material progress is believed to hold the key to a better future. ${ }^{39}$ For the sake of maximum economic growth, capitalism's creative destruction must be fully unleashed. ${ }^{40}$ Only minimal attention need be given to the non-economic costs. ${ }^{41}$

However, a substantial body of work in psychology, especially in what has come to be called "happiness research," finds that above a fairly low threshold, subjective well-being does not correlate with higher incomes and higher levels of consumption. Bigger houses, bigger cars, more expensive clothes and jewelry do not translate into 
greater happiness. Although it has been found that average levels of satisfaction are considerably lower in very poor countries than in rich ones, after a certain income level has been attained, further increases in income do not seem related to higher levels of subjective well-being (Diener and Diener 1995; Veenhoven 1993; Easterlin 2001, 2002).

If capitalism's increasingly robust creative destruction is generating greater insecurity and psychological stress, which in turn is a root cause of the obesity epidemic, then this epidemic is symptomatic of a social mistakethe seeking of maximum efficiency and economic growth even in those societies where the fundamental problem of material security has already been solved. ${ }^{42}$ Alongside ecological destruction, obesity may be one of the canaries dying in the mine. ${ }^{43}$

\section{REFERENCES}

Adam, Tanja C. and Elissa E. Epel. (2007) “Stress, eating, and the reward system.” Physiology and Behavior 91, 4: 449-458.

Alesina, Alberto, Ed Glaeser, and Bruce Sacerdote. 2002. "Why Doesn't the United States Have a European-Style Welfare State?" Brookings Papers on Economic Activity, 2, 187-277.

Alonso-Alonso, Miguel and Alvaro Pascual-Leone. (2007) “The Right Brain Hypothesis for Obesity.” Journal of the American Medical Association 297, 16: 1819-1822.

American Academy of Sleep Medicine. "Short Sleep Duration Linked To Obesity, Consistently and Worldwide." ScienceDaily 2 May 2008. 24 September $2008<\mathrm{http}: / /$ www.sciencedaily.com /releases/2008/05/080501062808.htm>.

Anderson, James W.; Elizabeth C. Konz; Robert C. Frederich, and; Constance L. Wood. (2001) "Long-term weightloss maintenance: a meta-analysis of US studies." American Journal of Clinical Nutrition 74, 5: 579-584.

Anderson, Patricia M. and Bruce D. Meyer. (1997) "Unemployment Insurance Takeup Rates and the After-Tax Value of Benefits," Quarterly Journal of Economics 112, 3: 913-37.

Anderson, Sarah E; Gerard E Dallal, and; Aviva Must. (2003) "Relative Weight and Race Influence Average Age at Menarche: Results From Two Nationally Representative Surveys of US Girls Studied 25 Years Apart." Pediatrics 111, 4: 844-850.

Anderson-Connolly, Richard. 2006. "The Problem with Growth as the Solution,” Challenge, 49 (1), January/February, 90-118.

Atkinson, Thomas, Ramsay Liem and Joan H. Liem. 1986. "The Social Costs of Unemployment: Implication for Social Support,” Journal of Health and Social Behavior, 27 (4), December: 317-331.

Bowles, Samuel and Yongjin Park. (2005) "Emulation, Inequality, and Work Hours: Was Thorstein Veblen Right?" The Economic Journal 115, 507: F397-F412.

Becker, Gary S., and K.M. Murphy. 1988. “A Theory of Rational Addiction,” Journal of Political Economy, 96: 675-700.

Björntorp, P. 2001. "Do Stress Reactions Cause Abdominal Obesity and Comorbidities?" Obesity Reviews, 2: 7386. 
Brunner, Eric J.; Tarani Chandola, and; Michael G. Marmot. (2007) "Prospective Effect of Job Strain on General and Central Obesity in the Whitehall II Study." American Journal of Epidemiology 165, 7: 828-837.

Burke, Mary A. and Frank Heiland. (2007) "Social Dynamics of Obesity." Economic Inquiry 45, 3: 571-591. *Note: Cite this instead of the Burke and Heiland (2006) working paper. Reference page 586 for "the full price per calorie has been roughly constant since 1993."

Caballero, Benjamin. 2007. "The Global Epidemic of Obesity: An Overview." Epidemiologic Reviews, 29, 1: 1-5.

Campos, Paul. (2004) The Obesity Myth: Why America's Obsession with Weight is Hazardous to Your Health. New York: Gotham Books.

Carr, Deborah, and Michael A. Friedman. 2005. "Is Obesity Stigmatizing? Body Weight, Perceived Discrimination, Psychological Well-Being in the United States," Journal of Health and Social Behavior, 46 (3), Sept: $244-59$.

Cartwright, M., J. Wardle, N. Steggles, A.E. Simon, H. Croker, and M.J. Jarvis. 2003. "Stress and Dietary Practices in Adolescents," Health Psychology, 22: 262-69.

Cawley, John. 2007. "The Economics of Childhood Obesity," Obesity, Business and Public Policy, Zoltan J. Acs and Alan Lyles, eds., Northhampton, Mass.: Edward Elgar, 27-56.

Center for American Progress Action Fund: http://blogs.moneycentral.msn.com/smartspending/archive/2008/11/25/unemployment-benefits-who-gets-leftout.aspx

Chakravarthy, Manu V. and Frank W. Booth. (2004) "Eating, exercise, and 'thrifty' genotypes: connecting the dots toward an evolutionary understanding of modern chronic diseases." Journal of Applied Physiology 96, 1: 3-10.

Chou, Shin-Yi, Michael Grossman, and Henry Saffer. 2004. "An Economic Analysis of Adult Obesity: Results from the Behavioral Risk Factor Surveillance System,” Journal of Health Economics, 23: 565-87.

Cleland, Richard; Dean C. Graybill; Van Hubbard; Laura Kettel Khan; Judith S. Stern; Thomas A. Wadden; Roland Weinsier, and; Susan Yanovski. (1998) Commerical Weight Loss Products and Programs: What Consumers Stand to Gain and Lose. Washington, DC: Federal Trade Commission, Bureau of Consumer Protection.

Cutler, David M.; Edward L. Glaeser, and; Jesse M. Shapiro. (2003) "Why Have Americans Become More Obese?" Journal of Economic Perspectives 17, 3: 93-118.

Dallman, Mary F.; Norman C. Pecoraro, and; Susanne E. la Fleur. (2005) "Chronic stress and comfort foods: Selfmedication and abdominal obesity." Brain, Behavior, and Immunity 19, 4: 275-280.

Dallman, Mary F., Norman Pecoraro, Susan F. Akana, Susanne E. La Fleur, Francisca Gomez, Hani Houshyar, M.E. Bess, Seema Bhatnagar, Kevin D. Laugero, and Sotara Manalo, 2003. "Chronic Stress and Obesity: A New View of 'Comfort Food'," Proceedings of the National Academy of Science USA, 100 (20), September: 11696-11701.

Davis, James Allan, Tom W. Smith, and; Peter V. Marsden. (2002) General Social Survey. Chicago: National Opinion Research Center.

de Sousa, Ronald. 2007. Why Think? Evolution and the Rational Mind. New York: Oxford University Press.

Diano, Sabrina, Susan A Farr, Benoit, Stephen C; Ewan C McNay; Ivaldo da Silva; Balazs Horvath; F Spencer Gaskin; Naoko Nonaka; Laura B Jaeger; William A Banks; John E Morley; Shirly Pinto; Robert S Sherwin; Lin Xu; Kelvin A Yamada; Mark W Sleeman; Matthias H Tschöp, and; Tamas L Horvath. 2006. "Ghrelin controls hippocampal spine synapse density and memory performance," Nature Neuroscience 9.3: 381-388. 
Diener, Ed, and Carol Diener (1995) "Factors Predicting the Subjective Well-Being of Nations." Journal of Personality and Social Psychology 69, 5: 851-64.

Doak, C. M., L.S. Adair, M. Bentley; C. Monteiro, and B.M. Popkin.(2005. "The dual burden household and the nutrition transition paradox." International Journal of Obesity, 29 (1): 129-36.

Dominitz, Jeff and Charles F. Manski. 1997. "Perceptions of Economic Insecurity: Evidence from the Survey of Economic Expectations." The Public Opinion Quarterly 61.2: 261-287.

Drewnowski Adam. 1995. "Energy Intake and Sensory Properties of food," American Journal of Clinical Nutrition, 6 (Supplement): 1081S-85S.

Drewnowski Adam; Colin D. Rehma, and; David Solet. (2007) "Disparities in obesity rates: Analysis by ZIP code area." Social Science and Medicine 65, 12: 2458-63.

Durkheim, Émile. 1897. Suicide: A Study in Sociology. J. Spaulding and G. Simpson, translators. New York: Free Press, 1966.

Easterlin, Richard. (2001) “Income and Happiness: Toward a Unified Theory.” Economic Journal 111, 473: 46584.

Ekman, Jan B. and Kristjan Lilliendahl. "Using Priority to Food Access: Fattening Strategies in DominanceStructured Willow Tit (Parus montanus) Flocks," Behavioral Ecology, 4 (3): 232-38.

Epel, Elissa; Rachel Lapidus; Bruce McEwen, and Kelly Brownell. (2001) "Stress may add bite to appetite in women: a laboratory study of stress-induced cortisol and eating behavior." Psychoneuroendocrinology 26, 1: $37-49$.

Euro RSCG Worldwide press release, 2001. "Consumers are snacking more, shopping less in wake of terrorist attacks,” November 05, http://retailindustry.about.com/library/holiday/01/bl_rscg110501.htm

Ferrie, Jane Elizabeth; Martin John Shipley; Michael Gideon Marmot; Stephen Alfred Stansfeld, and; George Davey Smith. (1998) "An uncertain future: the health effects of threats to employment security in white-collar men and women.” American Journal of Public Health 88, 7: 1030-1036.

Ferrie, Jane Elizabeth; Martin John Shipley; Stephen Alfred Stansfeld, and Michael Gideon Marmot. (2002) "Effects of chronic job insecurity and change in job security on self-reported health, minor psychiatric morbidity, psychological measures, and health related behaviors in British civil servants: the Whitehall II study." Journal of Epidemiology and Community Health 56, 6: 450-454.

Finkelstein, Eric A., Christopher J. Ruhm, and Katherine M. Kosa. 2005. "Ecoonomic Causes and Consequences of Obesity," Annual Review of Public Health, 26: 239-57.

Flegal, Katherine M. (2006) "Commentary: The epidemic of obesity—what's in a name?" International Journal of Epidemiology 35, 1: 72-74.

Flegal, Katherine M.; Barry I. Graubard, and; David F. Williamson. (2004) "Methods of Calculating Deaths Attributable to Obesity." American Journal of Epidemiology 160, 4: 331-8.

Flegal, Katherine M. C.L. Ogden, and C.I. Johnson. 2002. "Prevalence and Trends in Obesity Among US Adults," Journal of the American Medical Association, 288: 1723-27.

Fogel, Robert W. 1994. "Economic Growth, Population Theory, and Physiology: The Bearing of Long-Term Processes on the Making of Economic Policy," American Economic Review, 84 (3): 369-95. 
Friedman, K. E., L. K. Reichmann, P.R. Constanzo, A. Zeli, J.A. Ashmoore, and G.J. Musante. 2005. "Weight Stigmatization and Ideological Beliefs: Relation to Psychological Functioning in Obese Adults," Obesity Research, 13 (5): 907-16.

Gibson, Edward Leigh. (2006) "Emotional influences on food choice: Sensory, physiological, and psychological pathways." Physiology and Behavior 89, 1: 53-61.

Greeno, Catherine G. and Rena R. Wing. (1994) “Stress-induced eating.” Psychological Bulletin 115, 3: 444-464.

Greenspan, Alan. 1997. "Statements to Congress - Statements by alan Greenspan to the Senate Committee on the Budget and the Senate Committee on Finance," U.S. Senate, January 21, 1997, Federal Reserve Bulletin, March.

Gundersen, Craig, Brenda J. Lohman, Steven Garasky, susan Stewart, and Joey Eisenmann. 2008. "Food Security, Maternal Stressors, and Overweight Among Low-Income US Children: Results From the National Health and Nutrition Examination Survey (1999-2002)," Pediatrics, 122 (3), September: 529-40.

Gustafson, Timothy B. and David B. Sarwer. (2004) "Childhood sexual abuse and obesity." Obesity Reviews 5.3: 129-135.

Gylfason, Thorvaldur. (2007) “Why Europe Works Less and Grows Taller.” Challenge Magazine 50, 1: 21-39.

Hacker, Jacob S. 2006. The Great Risk Shift. New York: Oxford University Press.

Halford, J., J. Harrold, C. Lawton, and J. Blundell. 2005. "Serotonin (5-HT) Drugs: "Effects on Appetite Expression ad Use for the Treatment of Obesity," Current Drug Targets, 6 (2): 201-13.

Hannerz, Harald, Karen Albertsen,, Martin Lindhardt Nielsen, Finn Tuchsen, and Hermann Burr. 2004.

"Occupational Factors and 5-year Weight Change Among Men in a Danish National Cohort," Health Psychology, 23 (3): $283-88$.

Hedley, A. A.; C.L. Ogden; C.L. Johnson; M.D. Carroll; L.R. Curtin, and; K.M. Flegal. (2004) "Prevalence of Overweight and Obesity Among U.S. Children, Adolescents, and Adults." Journal of American Medical Association 291, 23: 2847-2850.

Helmchen L.A. and Henderson R.M. (2004) "Changes in the distribution of body mass index of white US men, 1890-2000.” Annals of Human Biology 31, 2: 174-81.

Hertzenberg, S. A., J. A. Alic, and H. Wial. 1998. New Rules for a New Economy: Employment and Opportunity in Postindustrial America. Ithaca, New York: Cornell University Press.

Hill, James O., and John C. Peters. 1998. "Environmental Contributions to the Obesity Epidemic,” Science, 280, May: 1371-74.

Ho, G. T. C., and J.C.N. Chan, 2008. "Burden of Obesity - lessons learnt from Hong Kong Chinese" Obesity Reviews, 9: 35-40.

Holtgrave, David R. and Richard Crosby. (2006) "Is Social Capital A Protective Factor Against Obesity and Diabetes? Findings from an Exploratory Study.” Annals of Epidemiology 16, 5: 406-408.

Inglehart, Ronald. (1990) Culture Shift in Advanced Industrial Society. Princeton, N.J.: Princeton University Press.

Irvin, George. 2007. "Growing Inequality in the Neo-liberal Heartland," Post-Autishtic Economics Review, 43: 123.

Keith, S.W.; Redden, D.T.; P.T. Katzmarzyk; M.M. Boggiano; E.C. Hanlon; R.M. Benca; D. Ruden; A. Pietrobelli; J.L. Barger; K.R. Fontaine; C. Wang; L.J. Aronne; S.M. Wright; M. Baskin; N.V. Dhurandhar; M.C. Lijoi; C.M. 
Grilo; M. DeLuca; A.O. Westfall, and; D.B. Allison. (2006) "Putative contributors to the secular increase in obesity: exploring the roads less traveled." International Journal of Obesity 30, 11: 1585-94.

Kelly, Shona J. and Clyde Hertzman. (2001) "Finding a stress measure in the literature and taking it into the field." Advances in Psychosomatic Medicine 22: 7-16.

Keynes, John Maynard. (1932) Essays in Persuasion. New York: Harcourt, Brace, and Co.

Kieselbach, Thomas. (2003) "Long-Term Unemployment Among Young People: The Risk of Social Exclusion." American Journal of Community Psychology 32, 1-2: 69-76.

Kinzie, Susan. 2008. "U.S. Lags in Providing College Access, Study Finds,” The Washington Post, December 3, A6.

Kivimäki, M.; J.E. Ferrie; E. Brunner; J. Head; M.J. Shipley; J. Vahtera1; et. al. (2005) "Justice at work and reduced risk of coronary heart disease among employees: The Whitehall II Study." Archives of Internal Medicine 165, 19: 2245-51.

Kivimäki, M.; J. Head; J.E. Ferrie; M.J. Shipley; E. Brunner; J. Vahtera, and; M.G. Marmot. (2006) "Work stress, weight gain and weight loss: evidence for bidirectional effects of job strain on body mass index in the Whitehall II study." International Journal of Obesity 30, 6: 982-87.

Kuo, Lydia E.; Joanna B. Kitlinska; Jason U. Tilan; Lijun Li; Stephen B. Baker; Michael D. Johnson; Edward W. Lee; Mary Susan Burnett; Stanley T. Fricke; Richard Kvetnansky; Herbert Herzog, and; Zofia Zukowska. (2007) "Neuropeptide Y acts directly in the periphery on fat tissue and mediates stress-induced obesity and metabolic syndrome." Nature Medicine 13, 7: 803-11.

Kusnet, David, Lawrence Mishel, and Ruy Teixeira. 2006. Talking Past Each Other: What Everyday Americans Really Think (and Elites Don't Get) about the Economy. Washington, D.C.: Economic Policy Institute.

Kyrou, Ioannis, George P. Chrousos, and Constantine Tsigos. 2006. "Stress, Visceral Obesity, and Metabolic Complications,” New York Academy of Sciences, 1083 (1), 77-110.

Laitinen, J., E. Ek, and U. Sovio. 2002. "Stress-Related Eating and Drinking Behavior and body Mass Index and Predictors of this Behavior," Preventive Medicine, 34 (1): 29-39.

Lane, Robert E. 1991. The Market Experience. New York: Cambridge University Press.

La Porta, Rafael et. al. 1999. “The Quality of Government,” Journal of Law, Economics and Organization, April 15: 222-79.

Lee, Joyce M.; Danielle Appugliese; Niko Kaciroti; Robert F. Corwyn; Robert H. Bradley, and; Julie C. Lumeng. (2007) "Weight Status in Young Girls and the Onset of Puberty." Pediatrics 119, 3: 624-30.

Lemeshow, Adina R., Laurie Fisher; Elizabeth Goodman; Ichiro Kawachi; Catherine S. Berkey, and Graham A. Colditz. 2008. "Subjective Social Status in the School and Change in Adiposity in Female Adolescents: Findings From a Prospective Cohort Study," Archives of Pediatrics and Adolescent Medicine, January, 162(1):23-28.

Livingston, Edward H. and Clifford Y. Ko. (2004) "Socioeconomic characteristics of the population eligible for obesity surgery." Surgery 135, 3: 287-96.

Lumeng, Julie C.; Danielle Appugliese; Howard J. Cabral; Robert H. Bradley; Barry Zuckerman. (2006) "Neighborhood Safety and Overweight Status in Children." Archives of Pediatric and Adolescent Medicine 60, 1: 25-31. 
Mann, Stefan. 2008. "Framing Obesity in Economic Theory and Policy," Review of Social Economy, 65 (2), June: $163-79$.

McLaren, Lindsay. (2007) “Socioeconomic Status and Obesity.” Epidemiologic Reviews 29, 1: 29-48.

Mellbin, T. and J.C. Vuille. 1989. "Rapidly Developing Overweight in School Children as an Indicator of Psychosocial Stress," Acta paediatrica Scandinavica, 78: 568-72.

Michaud, C.I.; J.P. Kahn; N. Musse; C. Burlet; J.P. Nicolas, and; I. Mejean. (1990) "Relationship between a critical life event and eating behavior in high-school students." Stress Medicine 6, 1: 57-64.

Miringoff, Marque-Luisa and Sandra Opdyke. 2008. America's Social Health: Putting Social Issues Back on the Public Agenda. Armonk, New York: M.E. Sharpe.

Mishel, L., J. Bernstein, and J. Schmitt. 1999. The State of Working America 1998-1999. Ithaca, New York: Cornell University Press.

Mill, John Stuart. 1848. Principles of Political Economy. Clifton, New Jersey: Augustus M. Kelly, 1973.

Miller, Diane B. and James P. O’Callaghan. (2002) “Neuroendocrine Aspects of the Response to Stress” Metabolism 51, 6: 5-10.

Morris, J.K., D.G. Cook, and A.G. Shaper. 1992. "Non-employment and Changes in Smoking, Drinking, and BodyWeight," British Medical Journal, 304 (6826), February 29: 536-41.

Murphy, Carolyn, Stephanie Ettinger De Cuba, John Cook, and Karen Jeng, Rachel Cooper and Jim Weill. 2008. "Reading, Writing and Hungry :The consequences of food insecurity on children, and on our nation's economic success," Partnership for America's Economic Success, November, Issue Brief \# 8, Washington, D.C.

Neel, James V. (1962) “Diabetes Mellitus: A ‘Thrifty’ Genotype Rendered Detrimental by 'Progress'?” American Journal of Human Genetics 14, 4: 353-62.

Nestle, Marion, and Michael F. Jacobson. 2000. "Halting the Obesity Epidemic: A Public Health Policy Approach," Public Health Reports, 115, January/February, 12-24.

Newman, Emily; Daryl B. O'Connora, and; Mark Connera. (2007) "Daily hassles and eating behavior: The role of cortisol reactivity status." Psychoneuroendocrinology 32, 2: 125-32.

Ng, Debbie M. and Robert W. Jeffery. (2003) "Relationships between perceived stress and health behaviors in a sample of working adults" Health Psychology 22, 6: 638-42.

Nord, Mark, and Margaret Andrews and Steven Carlson. 2004. "Household Food Security in the United States, 2003," Food Assistance and Nutrition Research Reports, 42, October: 1069.

Oliver, Georgina and Jane Wardle. (1999) "Perceived effects of stress on food choice." Physiology and Behavior 66, 3: 511-15.

Oliver, Georgina; Jane Wardle, and; E. Leigh Gibson. (2000) "Stress and Food Choice: A Laboratory Study." Psychosomatic Medicine 62, 6: 853-65.

Parenti, Christian. (1999) “Atlas Finally Shrugged: Us Against Them in the Me Decade,” The Baffler 13: 108-20.

Pagan, J. A., and A. Davila. 1997. "Occupational Attainment, and Earnings,” Social Science Quarterly, 78 (3): 756-70. 
Paul-Ebhohimhen, V. and A. Avenell. 2008. "Systematic review of the use of financial incentives in treatments for obesity and overweight." Obesity Reviews 9.4: 355-367.

Paxton, Pamela. (1999) "Is Social Capital Declining in the United States? A Multiple Indicator Assessment." American Journal of Sociology 105, 1: 88-127.

Philipson, Tomas. (2001) “The world-wide growth in obesity: an economic research agenda." Health Economics 10, 1: $1-7$.

Philipson, Tomas, and Robert A. Posner. 1999. "The Long-Run Growth in Obesity as a Function of Technological Change," National Bureau of Economic Research, Working Paper \# 7423.

Pickett, Kate E., Shona Kelly, Eric Bruner, Tim Lobstein, and Richard G. Wilkinson. 2005. "Wider Income Gaps, Wider Waistbands? An Ecological Study of Obesity and Income Inequality," Journal of Epidemiological Community Health, 59: 670-74.

Polivy, Janet and Peter Herman. (1999) “Distress and eating: why do dieters overeat?" International Journal of Eating Disorders 26, 2: 153-64.

Pond, Caroline M. (1998) The Fats of Life. Cambridge, U.K.: Cambridge University Press.

Public Health Service, US Department of Health and Human Services. 1996. Health United States 1995. Washington, D.C.: US Government Printing Office.

Puhl, Rebecca, and Kelly D. Brownell. 2001. “Bias, Discrimination, and Obesity,” Obesity Research, 9: 788-805.

Putnam, Robert D. (1995) “Bowling Alone: America's Declining Social Capital.” Journal of Democracy 6, 1: 6578.

Raleigh, M. J., M.T. McGuire, G.L. Brammer, D.B. Pollack, and A. Yuwiler. 1991. "Serotonergic Mechanisms Promote Dominance Acquisition in Adult Male Vervet Monkeys,” Brain Research, 559 (2): 181-90.

Rawls, John (1971) A Theory of Justice. Cambridge: Harvard University Press.

Rennie, K.L. and S.A. Jebb. (2005) "Prevalence of obesity in Great Britain.” Obesity Reviews 6, 1: 11-12.

Robinson, Thomas N.; Dina L. G. Borzekowski; Donna M. Matheson, and; Helena C. Kraemer. (2007) "Effects of Fast Food Branding on Young Children's Taste Preferences." Archives of Pediatrics and Adolescent Medicine 161: 792-7.

Røpke, Inge.1999. “The Dynamics of Willingness to Consume,” Ecological Economics, 28, 399-420.

Rosenwald, Michael S. 2006. "Why America Has to Be Fat: A Side Effect of Economic Expansion Shows Up in Front," The Washington Post, January 22, F1, F8.

Rosin, Odelia. 2008. "The Economic Causes of Obesity: A Survey,” Journal of Economic Surveys, 1-31.

Samuelson, Robert. 1996. "Downsizing for Growth," The Washington Post, March 21, A17.

Sapolsky, Robert M. 2005. "The Influence of Social Hierarchy on Primate Health." Science Magazine 308.648: 648652.

Sarkar, Sobhanjan, and Barun Mukhopadhyay. 2007. "Perceived Psychosocial stress and Cardiovascular Risk: Observations among the Bhutias of Sikkim, India," Stress and Health, 24: 23-34. 
Shell, Ellen Ruppel. (2002). The Hungry Gene: The Inside Story of the Obesity Industry. New York, N.Y.: Grove Press.

Schumpeter, Joseph A. 1962. Capitalism, Socialism, and Democracy. 3rd ed. New York, N.Y.: Harper Torchbooks (First published in 1942).

Schuster, Mark A.; Bradley D. Stein; Lisa H. Jaycox; Rebecca L. Collins; Grant N. Marshall; Marc N. Elliott; Annie J. Zhou; David E. Kanouse; Janina L. Morrison, and; Sandra H. Berry. (2001) "A National Survey of Stress Reactions after the September 11, 2001 Terrorist Attacks." The New England Journal of Medicine. 345.20: 150712.

Setterfield, Mark, and Ted Lovejoy. 2006. "Aspirations, Bargaining Power, and Macroeconomic Performance," Journal of Post-Keynesian Economics, 37 (1): 117-48.

[Shea, Christopher. 2006. “Empty-Stomach Intelligence.” The New York Times Magazine, 10 December: 46.

Smith, A.W.; A. Baum, and; R.R. Wing. (2005) "Stress and weight gain in parents of cancer patients." International Journal of Obesity 29, 2: 244-50.

Spiegel, K. and R. Laproult, and E. van Cauter. 1999. "Impact of Sleep Debt on Metabolic and Endocrine Function," The Lancet, 354: 1435-39.

Spritzer, D.A. 2004. “Obesity Epidemic Migrates East,” Canadian Medical Association Journal, 17 (10): 1159.

Stambor, Zak. (2006) “Stressed Out Nation.” Monitor on Psychology. 37, 4: 28.

Steffens, S., D. Casas, B. Milanez, C. Freitas, M. Paschoalini, and J. MarinoNeto. 1997. "Hypophagic and Dipsogenic Effects of Central 5-HT Injections in Pigeons," Brain Research Bulletin, 44 (6): 681-88.

Storm, Sara. (2003) “Unemployment and Families: A Review of Research.” The Social Science Review 77, 3: 399401.

Stunkard, Albert J., Jennifer R. Harris, Nancy L. Pedersen, and Gerald E. McClearn. 1991. "The Body-mass Index of Twins Who Have Been Reared Apart," New England Journal of Medicine, 149: 649-52.

Tanumihardjo, Sherry A., Cheryl Anderson, Martha Kaufer-horwitz, Lars Bode, Nancy J Emenaker, Andrea M Haqq, Jessie A Satia, Heidi J Silver, Diane D Stadler. 2007. "Poverty, Obesity, and Malnutrition: An International Perspective Recognizing the Paradox," Journal of the American Dietetic Association, 107 (11): 1966 - 1972.

Tataranni, P.A.; D. Larson; S. Snitker; J. Young; J. Flatt, and; E. Ravussin. (1996) "Effects of glucocorticoid on energy metabolism and food intake in humans." American Journal of Physiology 271, 2: E317-E325.

Veblen, Thorstein. 1919. The Place of Science in Modern Civilization. New York: B.W. Huebsch.

Veenhoven, Ruut (1993) Happines in Nations: Subjective Appreciation of Life in 56 Nations. Rotterdam: Erasmus University.

Vitaliano, Peter P.; Joan Russo; James M. Scanlan, and; Catherine G. Greeno. (1996) "Weight changes in caregivers of Alzheimer's care recipients: Psychobehavioral predictors." Psychology and Aging 11.1: 155-163.

Vlad, I. 2003. “Obesity Costs U.K. Economy 2bn a Year,” British Medical Journal, 327 (7427): 1308.

Wallace, Rodrick and Deborah N. Wallace. 2005. "Structured Psychosocial Stress and the US Obesity Epidemic," Journal of Biological Systems, 13 (4): 363-84. 
Wang, Youfa and May A. Beydoun. (2007) "The Obesity Epidemic in the United States-Gender, Age, Socioeconomic, Racial/Ethnic, and Geographic Characteristics: A Systematic Review and Meta-Regression Analysis.” Epidemiologic Reviews 29, 1: 6-28.

Wells, J.C.K. (1998) "Is obesity really due to high energy intake or low energy expenditure?" International Journal of Obesity 22, 11: 1139-40.

Whelan, Christopher T. (1994) "Social Class, Unemployment, and Psychological Distress.” European Sociological Review 10, 1: 49-61.

Whiting, Marjorie G. 1958. A Cross-Cultural Nutrition Survey of 118 Societies Representing the Major Cultural And Geographic Areas of the World. Harvard School of Public Health, Ph.D. Thesis. Boston.

R. A. Whitmer, R. A., and D. R. Gustafson, E. Barrett-Connor, M. N. Haan DrPH, E. P. Gunderson, and K. Yaffe. 2008. "Central obesity and increased risk of dementia more than three decades later," Neurology (online journal), 0: 01.wnl.0000306313.89165.efv1

Wilkinson, Richard. G. 2005. The Impact of Inequality. New York: Routledge.

Willox, J.; J. Corr; J. Shaw; M. Richardson, and; K. Calman. (1984) "Prednisolone as an appetite stimulant in patients with cancer." British Medical Journal 288, 6410: 27.

Wisman, Jon D. (2003) “The Scope and Promising Future of Social Economics." Review of Social Economy 61, 4: $425-45$.

Wisman, Jon D. 2006. "Creative Destruction and Community," in Ethics and the Market: Insights from Social Economics. Edited by Betsy Jane Clary, Wilfred Dolfsma, and Deborah M. Figart. London: Routledge, Chapter 3, pp. 26-40.

Wisman, Jon D. 2009. "Household Saving, Class Identity, and Conspicuous Consumption," Journal of Economic Issues, 63 (1), March 2009: 89-114.

Wolff, Edward N. (1998) "Recent Trend in the Size Distribution of Household Wealth." Journal of Economic Perspectives 12, 3: 131-50.

World Health Organization. 1998. "Obesity: Preventing and Managing the Global Epidemic. Report of a Consultation on Obesity" WHO, Geneva, June: 3-5.

World Health Organization. (2000) Obesity: preventing and managing the global epidemic. Report of a WHO Consultation on obesity. Geneva, Switzerland: World Health Organization. (WHO technical report series 894).

Wu, Yangfeng. 2006. "Overweight and Obesity in China,” British Medical Journal, 333: 362-63.

Yang, Wenjie; Kelly Tanika; Jiang He. (2007) “Genetic Epidemiology of Obesity.” Epidemiologic Reviews 29, 1: 49-61.

Zellner, Debra A.; Susan Loaiza; Zuleyma Gonzalez; Jaclyn Pita; Janira Morales; Deanna Pecora, and; Amanda Wolf. (2006) "Food selection changes under stress." Physiology and Behavior 87, 4: 789-93.

Zhang, Qi and Youfa Wang (2004) "Trends in the Association between Obesity and Socioeconomic Status in U.S. Adults: 1971 to 2000.” Obesity Research 12, 10: 1622-32.

\section{NOTES}


${ }^{1}$ Obesity is characterized by excessive body fat and defined for adults (over 20 years of age) as a 'body mass index' (BMI, the ratio of weight in kilograms to height in meters squared) of $30 \mathrm{~kg} / \mathrm{m}^{2}$ or greater. Extreme obesity is defined as BMI $\geq 40 \mathrm{~kg} / \mathrm{m}^{2}$. The Center for Disease Control and Prevention (CDC) does not define "obesity" for youths (2-19 years of age). Instead, overweight is defined for youths as a BMI above the 95th percentile for sexspecific age growth charts.

The prevalence of overweight among American youths has also increased dramatically since 1980. Prevalence doubled among children and tripled among adolescents. Specifically, between 1980 and 2000, overweight among children ages 2-5 and 6-11 increased from 5.0 percent to 10.4 percent and from 6.5 percent to 15.3 percent, respectively. Among adolescents (12-19 years of age), overweight increased from 5.0 percent to 15.5 percent (Ogden et. al. 2002). Gundersen et al, drawing on more recent data, provide even higher estimates, claiming that "Approximately $17.1 \%$ of US children between the ages of 2 and 19 years are obese, and another $16.5 \%$ are overweight" (2008: 530).

${ }^{2}$ Overweight is defined for adults as a BMI of $25 \mathrm{~kg} / \mathrm{m}^{2}$ or greater.

${ }^{3}$ Many in the developing world still live on less than one dollar a day. The consequences of such poverty include chronic hunger, undernutrition, and underweight as well as increased vulnerability to disease and starvation. Given extreme inequality, it is hardly surprising that over- and under-weight persons coexist worldwide. What is surprising is that within developing countries, over- and under-weight persons - typically an overweight female and underweight child — often cohabitate in the very same household, so-called "dual burden" households (Doak et. al. 2005).

${ }^{4}$ Caballero notes that "By the year 2000, the human race reached a sort of historical landmark, when for the first time in human evolution the number of adults with excess weight surpassed the number of those who were underweight" (2007: 1).

5 This hypothesis parallels and expands upon that of Wallace and Wallace (2005), who contend that:

"The fundamental cause of the US obesity epidemic is a massive threat to the population caused by continuing deterioration of basic US social, economic, and related structures, in the particular context of a ratcheting of dominance relations resulting from the concentration of effective power within a shrinking elite.... [which they view as] the consequences of public policies" $(382 ; 364)$.

Björntorp also notes in passing the possibility that the stress of "a very competitive society" may have a causal role in explaining obesity (2001: 80). The pioneer in studying the relationship between economic stress and health was Émile Durkheim (1897). He found that anomie increased during periods of great change, and especially during periods of economic turbulence.

${ }^{6}$ Abdominal fat, or "central obesity," is defined for adult males and females as a waist circumference of 40 and 30 inches or greater, respectively. It is often viewed as a better measure than BMI of the health risks of obesity. The prevalence of central obesity has also increased dramatically since 1980 (Wang and Beydoun 2007). Björntorp reports that evidence indicates "that centralization of body fat most likely is a consequence of the endocrine perturbations characteristic of chronic stress reactions" (2001: 78).

7 This conforms to the social gradient to health. People tend to be sicker and to die sooner the lower they find themselves on the socio-economic ladder.

${ }^{8}$ As Hill and Peters put it, "while the body has excellent physiological defenses against the depletion of body energy stores, it has weak defenses against the accumulation of excess energy stores when food is abundant" (1998: 1371).

9 When the stomach is empty, ghrelin, an appetite-stimulating hormone is secreted. In one study, when mice were injected with ghrelin, they performed better at intelligence tests (e.g., running a maze) than control mice with lower, normal levels (Diano et. al. 2006). This "empty-stomach intelligence" may well have been an evolutionary adaptation: "When you're hungry, you need to focus your entire system on finding food in the environment" (Shea 2006: 46). Thus, should this apply to humans as well as mice, then reversing the obesity epidemic might make people smarter. Obese persons have lower levels of ghrelin compared to lean persons, and studies show that overweight and obesity are associated with poorer academic performance. 
10 A popular rallying cry of the French Revolution was Le Peuple contre les gros (the people against the fat cats). Philipson notes that "In the nineteenth century, thinness was a signal of malnutrition and tuberculosis, and fatness a signal of prosperity; stout men and women were therefore considered handsome and stout women beautiful and sexy" (2001: 2).

${ }^{11}$ It is ironic that whereas increasing the availability of fat and sugar was once seen as important for increasing the productivity of the working class, today many express the view that such availability must be curbed because the obese are believed to be less productive. It has even been proposed that a 'fat' or 'Twinkie' tax be levied on unhealthy foods to reduce the prevalence of obesity (e.g., Nestle and Jacobson 2000).

12 Today, thinness, by contrast, "can be perceived as a signal of trustworthiness, because it could be taken to indicate a degree of self-control or self-discipline" (Philipson 2001: 2).

13 This view is well captured by Tomas J. Philipson, an economics professor at the University of Chicago: "The obesity problem is really a side effect of things that are good for the economy. But we would rather take improvements in technology and agriculture than go back to the way we lived in the 1950s when everyone was thin. Nobody wants to sweat at work for 10 hours a day and be poor. Yes, you're obese, but you have a life that is much more comfortable" (cited in Rosenwald 2006: F1, F8).

14 However, Robert Fogel (1994) claims that during most of the twentieth century, Americans weighed less than what would be ideal for maximum life-span.

15 It is striking how little additional consumption of calories is necessary to account for the obesity epidemic. As Finkelstein et. al. put it, "the rise in obesity rates could be explained by as little as an average net increase of 50-100 calories per day, which is less than half the calories in a 16 ounce carbonated beverage" (2005: 241).

16 Beyond economists, among the psychological explanations of obesity offered by students of the problem, Drewnowski and Specter list "inadequate nutrition knowledge, excessive vulnerability to the external environment, addictive personality, and the consumption of high-fat foods in search of comfort" (2004: 13).

17 Within Christianity, as in all major world religions, gluttony is viewed as sinful. Yet obesity is as prevalent among Americans who profess to being religious (the overwhelming majority), as among non-believers (Mann 2008).

18 However, economists appear ever resistant to overly relaxing their rationality assumptions, even if what is required is the crafting of concepts such as "rational addiction" (Becker and Murphy 1988). Nevertheless, some are willing to make an exception for children. As John Cawley points out, “...when the economic framework is applied to children, one must take into account that children are not perfectly rational....there is abundant evidence that children are incapable of weighing the future consequences of their actions" (2007: 32).

${ }^{19}$ It ignores, for instance, any effect from advertising. Yet the effects of advertising, particularly on children, have been well-documented. A recent study found that out of 63 children (ages 3-5 from low-income families), a majority thought that hamburgers (roughly 48 percent), chicken nuggets (59 percent), French fries ( 77 percent), milk (or apple juice for one child not allowed to drink milk, 61 percent), and carrots (54 percent) from a McDonald's packaging tasted better than the identical items from plain packaging. Children with more televisions in their home and those who went to McDonald's more often were more likely to prefer the "McDonald's" food (Robinson et. al. 2007: 792-97). Other studies have found that "An increase in advertising increases both BMI and the probability of being overweight in children and adolescents" (Rosin 2008: 24).

20 Cutler, Glaeser, and Shapiro (2003) admit that the rational choice model cannot adequately account for the obesity epidemic and that "at least some food consumption is almost certainly not fully rational" (112). They claim that "people with self-control problems may find themselves overconsuming food, particularly when the time costs of food preparation fall" (113). Given the extraordinary personal costs associated with obesity, it is not convincing that individuals' self control could be so imbalanced by a decline in the costs of food preparation. Although they are 
willing to relax the rationality assumption ("nonrational discounting"), they do not address the possibility that nonpecuniary social forces might be influencing individuals' choices.

${ }^{21}$ They go on to note advertising (2004: 13). Other environmental factors noted by Caballero are long car commutes that restrict opportunities for walking, limited and/or unsafe recreational facilities, and prepared foods (2007: 3).

22 It is conceivable that an increase in stress caused by increased insecurity could raise cortisol levels which in turn would lead individuals to overly discount the future. That is, raised cortisol levels would lower the signal of satiety, prompting the individual to over-estimate the benefit of eating more and thereby not adequately take into account the full consequences of over-consuming calories and expending too few. In other words, present decision making is utility maximizing and therefore rational, even if when taken together with the long-run consequences it is no longer rational. This would permit such behavior to fit into the rational choice model. However, it seems that doing so has little if any explanatory value. As philosopher Ronald de Sousa has pointed out, "In the context of the most restricted framework, all action is by definition rational. This basic sense of rationality is admittedly trivial, even tautological, since it follows simply from the fact that the agent does something "because she wants to"' (2007: 32).

${ }^{23}$ The classic study of food shortages among hunter-gatherer and subsistence agricultural peoples was carried out by Marjorie Whiting. In her study of 118 traditional societies all over the world, all were found to suffer periodic food shortages: 25 percent every 10 to 15 years; 25 percent every two to three years; 23 percent each year for at least a brief period; and 23 percent more than once a year (1958).

${ }^{24}$ In an evolutionary sense, births optimally occur when there is security, when food is relatively abundant. Thus the contemporary exploding number of overweight children may be responsible for the earlier onset of puberty. Among girls, a higher BMI is associated with earlier menarche after controlling for age and race (Anderson, Dallal, and Must 2003). Longitudinal studies also suggest that heavier weights cause an earlier onset of breast development and menarche (Lee, et. al. 2007). Force-feeding of young girls, a practice in some traditional cultures, also suggests such causality.

${ }^{25}$ Other energy-burning activities like growth, immunity, and reproduction are also temporarily suppressed. Although this article explores a possible link between chronic stress and obesity, another possible physiological effect of chronic stress might be shorter stature. Gylfason (2007: 32) speculates that cross-country differences in average height among developed countries may be partially attributed to inequality and working hours, both of which may generate stress.

${ }^{26}$ This index measures one-quarter of median family income as percent of the funds necessary to qualify for an 80 percent mortgage on a median-priced home.

27 Interestingly, the survey also found that " 21 percent of participants who ate at a fast-food restaurant in the week prior to the survey reported being very concerned about stress, while only 13 percent of people who did not eat at a fast-food restaurant in the week prior to the survey were very concerned about stress" (Stambor 2006: 28).

${ }^{28}$ Overweight people tend to eat more when stressed, lean people less. Individuals may also vary in their tolerance of stress levels.

29 There have, nevertheless, been attempts to create an index of job insecurity. See, for instance, Setterfield and Lovejoy 2006.

${ }^{30}$ Unfortunately, only fruit, vegetable, and fiber consumption within diets were considered, thus ignoring a possible role for high-sugar and high fat foods.

${ }^{31}$ A study by Dominitz and Manski (1997) shows that those of lower socioeconomic status (based on educational attainment or race) report greater insecurity (in terms of the probability of job loss during the next year, probability of having no health insurance in a year, probability of being the victim of a burglary during the next year). 
32 In another study (Ferrie et. al. 2002) found that chronic job insecurity was associated with a decrease in mean BMI among women.

33 The Gini coefficient, a common measure of the degree of inequality, increased in the U.S. from 0.403 in 1980 to 0.469 in 2005 (Miringoff and Opdycke 2008: 234). The Gini coefficient is a measure of income shares received by households along the income distribution. A coefficient of 0 indicates complete equality; a coefficient of 1 indicates complete inequality.

34 However, Zhang and Wang (2004) find that the association between educational achievement and obesity has weakened since the 1970s. This may reflect greater within-group inequality, or it may be that growing insecurity for everyone is eroding this benefit of education.

${ }^{35}$ Social capital is: “...the idea that individuals and groups can gain resources from their connections to one another (and the type of these connections). These resources can be used to produce certain goods" (Paxton 1999: 89).

${ }^{36}$ However, they speculate that this may be due to an exercise deficit because parents in unsafe neighborhoods may be less likely to permit their children to play outside.

37 As Finkelstein et. al. note, "the largest growth in viewing hours occurred during the early 1960s and mid-1970s, when color television first became widely available at relatively low prices... [and] only television viewing [and not time spent in front of computer and video games] has been shown to increase snacking, portion sizes, the percentage of calories from fat, and calories..." (2005: 246).

38 This has led Shin-Yi, et. al to suggest that their economic model for explaining the obesity epidemic "is missing a variable that can offset the positive impact of declines in smoking on obesity" 2004: 584). Our hypothesis identifies insecurity and stress as what they have missed.

39 Thus, for example, John Maynard Keynes foresaw a radical transformation of the human condition to be consequent to material abundance:

"I see us free, therefore, to return to some of the most sure and certain principles of religion and traditional virtue -- that avarice is a vice, that the exaction of usury is a misdemeanour, and the love of money is detestable, that those walk most truly in the paths of virtue and sane wisdom who take least thought for the morrow. We shall once more value ends above means and prefer the good to the useful. We shall honour those who can teach us how to pluck the hour and the day virtuously and well, the delightful people who are capable of taking direct enjoyment in things, the lilies of the field who toil not, neither do they spin.

But beware! The time for all this is not yet. For at least another hundred years we must pretend to ourselves and to every one that fair is foul and foul is fair; for foul is useful and fair is not. Avarice and usury and precaution must be our gods for a little longer still. For only they can lead us out of the tunnel of economic necessity into daylight." (Keynes 1930: 371-72).

${ }^{40}$ According to this vision, if unfettered growth unleashes greater stress, so much the better. Stress is presumably good for the economy. Thus Alan Greenspan, former Chair of the Federal Reserve System described the economy's performance in 1997 as "extraordinary" and "exceptional," noting that a felicitous force aiding this performance was a "heightened sense of job insecurity and, as a consequence, subdued wages" (Greenspan 1997).

${ }^{41}$ The material progress ideology has been extensively treated in Wisman (2003).

42 This social mistake is well expressed by popular economics journalist Robert J. Samuelson. Writing in celebration of corporate downsizing and worker insecurity, he claims that "...the anxieties and uncertainties that unsettle people may make them more prudent and productive in ways that strengthen and stabilize the economy" (1996: A17).

The view of economic growth as the panacea for all problems has Error! Main Document Only.prompted Richard Anderson-Connolly to note that: 
"There is some powerful type of irrationality or deception at work when many people can simultaneously recognize that the problems of insecurity and poverty have shown little or no improvement (and perhaps a worsening) over the last, say forty years, despite the enormous growth in the economy, yet at that same time they believe that economic growth in the future will eliminate problems like insecurity and poverty" (2006: 113).

43 And, as Hill and Peters put it, "To combat the epidemic of obesity, we much first cure the environment" (1998: 1373). 